\title{
The Impact of Corporate Governance and Ownership Structure on Earnings Management Practices: Evidence from Listed Companies in Pakistan
}

\author{
Kamran* and Attaullah Shah**
}

\begin{abstract}
This study analyzes the impact of corporate governance and ownership structure on earnings management for a sample of 372 firms listed on the Karachi Stock Exchange over the period 2003-10. We estimate discretionary accruals using four well-known models: Jones (1991); Dechow, Sloan, and Sweeney (1995); Kasznik (1999); and Kothari, Leone, and Wasley (2005). The results indicate that discretionary accruals increase monotonically with the ownership percentage of a firm's directors, their spouses, children, and other family members. This supports the view that managers who are more entrenched in a firm can more easily influence corporate decisions and accounting figures in a way that may serve their interests. This finding is consistent with prior research evidence on the role of dominant directors in expropriating external minority shareholders in Pakistan. Further, our results indicate that institutional investors play a significant role in constraining earnings management practices. We do not find any evidence that CEO duality, the size of the auditing firm, the number of members on the board of directors, and ownership concentration influence discretionary accruals. Among the control variables, we find that firms that are more profitable, are growing, or have higher leverage actively manage their earnings, while earnings management decreases with the age of the firm. The results are robust to several alternative specifications.
\end{abstract}

Keywords: Corporate governance, earnings management, ownership structure, discretionary accruals, KSE, Pakistan.

JEL classification: G32, G3, M4.

\section{Introduction}

Corporate governance refers to the "set of mechanisms through which outside investors protect themselves against expropriation by the insiders" (La Porta, López-de-Silanes, Shleifer, \& Vishny, 2000), where "insiders" include the controlling shareholders and management. The

\footnotetext{
* Institute of Management Sciences, Peshawar, Pakistan.

** Assistant Professor of Finance, Institute of Management Sciences, Peshawar, Pakistan.
} 
main objective of corporate governance is to protect the rights of stockholders and creditors and to ensure that the interests of insiders and outsiders converge. Good corporate governance can contribute to a country's social and economic development by enabling corporations to perform better.

The 1997 Asian financial crisis, which exposed weak governance in many corporations, made the business community more sensitive to the need to examine the effectiveness of corporate governance systems within firms. In the following years, as increasing instances of fraud surfaced in the financial statements of several large corporations such as Enron, WorldCom, Tyco International, Aldelphia, Parmalat, the Taj Company and, very recently, the Olympus Corporation, many countries drafted codes of corporate governance to improve their corporate governance mechanisms. One of the key tasks of a corporate governance structure is to make sure that financial reporting procedures are transparent.

Earnings management refers to attempts by firm managers to manipulate accounting figures, thereby making their financial statements less transparent. While there is no consensus on the definition of earnings management practices (Beneish, 2001), a widely accepted definition by Healy and Wahlen (1999) is that "earnings management happens when managers use judgment in financial reporting to either deceive some stakeholders about the underlying economic performance of the firm or to manipulate contractual outcomes that rely on reported accounting numbers."

Earnings management entails purposeful involvement in a firm's external financial reporting procedures with the intention of personal gain (Schipper, 1989). It is legal if the described profits are modified in line with generally accepted accounting principles (GAAP), for example, changing the procedure for inventory estimation and depreciation. Earnings management becomes fraudulent, however, when it goes beyond GAAP, such as accelerating income acknowledgment and deferring cost recognition (Yang, Chun, \& Shamsher, 2009).

Financial statements present important information to outside firm stakeholders. Investors' heavy reliance on financial data gives managers a strong incentive to alter financial statements for their own benefit. Such incentives may stem from career security, contractual obligations between outside stakeholders and managers, personal concerns in the existence of the compensation system, or the need to meet target earnings and market expectations (Healy \& Wahlen, 1999). Earnings management can take 
numerous forms, for example, structuring certain revenues, expenses, and transactions; altering accounting measures; and accruals management. Among these, accruals management is harmful to the integrity of financial information because shareholders are often ignorant of the scope of such accruals (Mitra, 2002).

Corporations generally set annual earnings targets, which they might exceed or fall short of in different cases. For this purpose, managers use accruals to manage actual earnings and present their investors with a sound picture of the firm's targets achieved. However, total accruals do not necessarily represent earnings management. Rather, they are divided into discretionary and nondiscretionary accruals where only the formerfor example, income-increasing and income-decreasing discretionary accruals-reflect earnings management. Investors are often ignorant of such actions and are thus vulnerable to making ineffective decisions based on manipulated information.

In 1999, the Organization for Economic Co-operation and Development developed a set of basic criteria for judging a country's corporate governance performance. The Securities and Exchange Commission of Pakistan (SECP) issued the Pakistani Code of Corporate Governance (PCCG) in March 2002 for the purpose of improving corporate governance practices and reducing the trust deficit among the business community, owners, and agents. The code consists of 47 clauses and sub-clauses, each covering some aspect of corporate governance standards. In conjunction with the Economic Affairs Division and UNDP, the code was implemented the same year.

In order to examine corporate governance practices in Pakistan, the SECP and International Financial Corporation conducted a survey in 2007, which revealed the need to create awareness of corporate governance among boards of directors. The Karachi Stock Exchange (KSE) undertook a similar initiative and set up a board to monitor firms' compliance with the PCCG. In the last two years, the SECP has increased its monitoring of corporations to enhance the quality of their disclosures.

Despite such steps, Pakistan's corporate governance environment is still not mature enough and insider-controlled businesses remain common (Javid \& Iqbal, 2008). Existing studies show that insider-controlling shareholders play a dominant role in many corporate decisions. Abdullah, Shah, Iqbal, and Gohar (2011) investigate whether corporate dividend payouts in Pakistan are determined by minimizing the transaction costs of 
external finance or by the relative power of insider-controlling shareholders and external shareholders. The authors consider nonpayment of dividends an indication of the expropriation of external minority shareholders. They conclude that, in the absence of powerful external shareholders, insider-controlled firms will not willingly pay out dividends. This evidence suggests that insider-controlled businesses have the potential to expropriate minority shareholders.

Does the market see such businesses negatively? Abdullah, Shah, and Khan (2012) study 183 firms listed on the KSE between 2003 and 2008 and find that insider-controlled firms perform poorly in terms of marketas well as accounting-based measures. This provides the rationale for the present study to develop and test several hypotheses related to ownership structure and earnings management in Pakistan. We argue that the presence of insider-controlled businesses should result in a higher incidence of earnings management. Control over decision rights gives owner-managers enough power to expropriate external minority shareholders in different ways, while earnings management can serve as an effective tool to this end.

Few studies have focused on assessing the relationship between earnings management and corporate governance and ownership structure in Pakistan's context. Shah, Zafar, and Durrani (2009), who investigate the relationship between board composition and earnings management for 120 companies listed on the KSE between 2003 and 2007, fail to find any significant association between these variables. However, their study includes only two variables and does not consider other important board composition and control variables.

Shah, Butt, and Hassan (2009) investigate the association between earnings management practices and corporate governance mechanisms. Their sample of 53 firms listed on the KSE-100 index in 2006 yields significant results. The positive association between corporate governance and earnings management is surprising, but may be explained by the fact that (i) the sample period is only a year long, and (ii) Pakistani firms were in transition after the promulgation of the PCCG in 2002, which then brought about a tendency to boost discretionary accruals as a risk aversion measure.

The present study aims to include all nonfinancial firms listed on the KSE over the period 2003-10 to assess the impact of ownership structure and corporate governance on earnings management. We 
include several important explanatory variables such as ownership concentration, institutional ownership, managerial ownership, audit quality, chief executive officer (CEO) duality, and board size alongside an extensive set of control variables.

The study contributes to the literature on several counts. First, it provides evidence on earnings management practices for a country where insider-controlled firms are ubiquitous. Such firms are characterized by a different set of agency problems compared to widely held firms. Unlike the latter, where the conflict of interest is between managers and shareholders, insider-controlled firms feature a conflict of interest between majority and minority shareholders. Dominant insiders can easily manipulate accounting figures in their favor. This makes it relevant to test whether governance mechanisms to control earnings management practices are effective in the presence of dominant corporate insiders. We use the percentage of shares owned by a firm's directors, their spouses, children, and other family members as a proxy for insider dominance.

Second, unlike other Pakistan-based studies, we use four different models to calculate discretionary accruals as a proxy for earnings management: (i) Jones (1991), (ii) Dechow, Sloan, and Sweeney (1995), (iii) Kasznik (1999), and (iv) Kothari, Leone, and Wasley (2005). The existing literature on discretionary accruals does not conclusively support any one specific model. Aaker and Gjesdal (2010) argue that the detection of earnings management through financial statements often requires jointly testing accrual models and earnings management; relying on one model alone can yield misleading results. Apart from employing four of the most widely used models for detecting earnings management, we also calculate their average value of discretionary accruals as a robustness check.

Third, compared to existing studies on Pakistan, ${ }^{1}$ we use a larger dataset in terms of sample period and number of firms. Where our sample comprises 370 firms between 2003 and 2010, other studies have used data for 120 firms or fewer and for a period of up to five years.

The rest of the study is organized as follows. Section 2 discusses the literature on earnings management and the role of ownership structure in association with corporate governance; this leads to the development of our hypotheses. Section 3 describes the data and

\footnotetext{
${ }^{1}$ As mentioned above, only two other studies have examined corporate governance and earnings management in Pakistan: Shah, Zafar et al. (2009) and Shah, Butt et al. (2009).
} 
methodology of the study, followed by an analysis of the results in Section 4 . Section 5 presents a conclusion and policy implications.

\section{Literature Review}

While there is no consensus on the impact of corporate governance on earnings management (Siregar \& Utama, 2008), several studies have investigated the relationship between the two variables and, in most cases, found a significant association (see, for example, Saleh, Iskandar, \& Rahmat, 2005; Shen \& Chih, 2007; Liu \& Lu, 2007; Lo, Wong, \& Firth, 2010; Bekiris \& Doukakis, 2011; Chen, Elder, \& Hsieh, 2007). Karamanou and Vafeas (2005) examine the relationship between corporate boards, audit committees, and earnings management and present results that are consistent with the literature.

Corporate ownership structure can potentially affect the monitoring mechanisms used to control agency costs and earnings management activities (Siregar \& Utama, 2008). Javid and Iqbal (2008) note that, in Pakistan, company ownership is commonly concentrated in the hands of a few large stockholders. They also argue that, in most emerging markets (such as Pakistan), closely held firms-controlled by families, the state, or financial institutions-tend to dominate the corporate scenario.

Different proxies can be used to gauge ownership structure. García-Meca and Ballesta (2009), for example, use ownership concentration, institutional ownership, and managerial ownership to measure ownership structure and investigate its relationship with earnings management. Cornett, Marcus, and Tehranian (2008) use institutional and managerial ownership as proxies for ownership structure. In this study, we use ownership concentration, institutional ownership, and managerial ownership to measure ownership structure, while CEO duality, audit quality, and board size are used as proxies for board characteristics. The following sections discuss each proxy and its association with earnings management.

\subsection{Institutional Ownership and Earnings Management}

Institutional investors have a strong incentive to gather information about the corporations in which they have invested or intend to invest. Further, such motivation grows with the level of investment involved. Large ownership is likely to spur institutions to actively observe any manipulation of earnings and relevant policy decisions (Mitra, 2002). 
There are two schools of thought concerning the role of institutional ownership in deterring earnings management. In the first view, institutional investors have both the power and incentive to restrict opportunistic behavior by executives in the form of earnings management practices. In the second view, institutional investors are often more concerned with short-term returns and are not interested in controlling managers: they would rather sell their stakes than monitor or remove incompetent management.

Chung, Firth, and Kim (2002) argue that large institutional shareholders with a substantial stake can deter earnings management because they have the incentive and resources to monitor it. They also note that, under the GAAP rules, managers may be tempted to transfer profits from one accounting period to the next in order to take advantage of bonuses or promotions by using reported income-increasing or decreasing accruals. Institutional investors are often long-term investors and discourage earnings management. Their advanced level of knowledge and experience, coupled with their substantial stake in a company, leads to decreasing information asymmetry between owners and agents, making it harder for the latter to manipulate earnings (AlFayoumi, Abuzayed, \& Alexander, 2010).

High levels of institutional ownership and low levels of company performance can deter managers' incentives to employ income-increasing discretionary accruals (Chung et al., 2002). This is because, in most cases, institutional investors are long-term investors who want to maximize company performance and share value rather than encourage earnings management. Bushee (1998) provides evidence that institutional investors create fewer incentives for management to cut R\&D expenditure in order to attain short-term targets and play a key role in monitoring management behavior. Other studies such as Majumdar and Nagarajan (1997), Cheng and Reitenga (2000), and Rajgopal and Venkatachalam (1997) present results that are consistent with this view.

In the second view, institutional investors are short-term-oriented, which some studies refer to as being transient or myopic: such owners focus primarily on current rather than long-term earnings (Bushee, 2001). They engage less in monitoring the management, and if they sense something is amiss, they would rather sell their shares than remove or monitor inefficient managers (Coffee, 1991). 
Bhide (1993) notes that institutional owners' involvement in corporate governance is bound to be inactive either because of their transient or fragmented ownership. Transient institutional owners may trade off control for liquidity (Coffee, 1991). Hsu and Koh (2005) investigate the impact of long-term and short-term institutional ownership on the degree of earnings management in Australian corporations. Their results provide evidence that long-term institutional and transient owners can coexist and have different impacts on earnings management. Transitory institutional owners are associated with income-increasing accruals, while long-term institutional owners are likely to deter this activity.

Charitou, Lambertides, and Trigeorgis (2007) examine managers' earnings behavior in times of financial distress, using a sample of 859 US firms that filed for bankruptcy from 1986 to 2004. They show that such companies' management with higher (lower) institutional ownership is less (more) likely to engage in downward earnings management, respectively. Roodposhti and Chashmi (2011) find a significant positive relationship between earnings management and institutional ownership for a sample of firms in Iran.

In light of the above discussion, we hypothesize that institutional ownership has a negative effect on earnings management (H1). To account for the transient nature of intuitional investors, we test this hypothesis using the 2SLS regression technique.

\subsection{Managerial Ownership and Earnings Management}

While the division of control and ownership in corporations is now common in the modern business environment, it also creates a severe conflict of interest between owners and agents. Managers who possess power may have an incentive to use firm resources for their own benefit and expropriate wealth in terms of bonuses or other benefits at the cost of shareholders (Beasley, 1996; Fama, 1980). Berle and Means (1932) argue that, whenever a little equity is held by the managers of a firm whose owners are scattered, then the former will use the firm's resources for their own benefit rather than for the benefit of their shareholders. Legally, managers are bound to utilize resources effectively and efficiently in order to maximize shareholders' wealth. However, as rational actors, managers tend to make choices that mostly benefit them (Eccles, 2001).

What happens when we increase the ownership stake of managers in a firm? The answer is not straightforward, but can be addressed using 
two hypotheses: (i) alignment of interest and (ii) entrenchment. The alignment-of-interest hypothesis states that, when managers' ownership stake in a firm increases, it reduces the agency conflict between shareholders and managers (Jensen \& Meckling, 1976). This should, in turn, reduce the scope for opportunistic behavior on the part of managers. Consistent with this idea, Demsetz and Lehn (1985) find a positive association between managerial ownership and firm performance.

The entrenchment hypothesis states that ownership stakes beyond a certain level put managers in a dominant position, which they can use to exploit external minority shareholders (Morck, Shleifer, \& Vishny, 1988). Teshima and Shuto (2008), who investigate the association between managerial ownership and earnings management in Japanese firms, have developed a theoretical model according to which earnings management incentives are lower when the level of managerial ownership is either low or high; incentives are higher at an intermediate level of managerial ownership. Thus, there is a cubical or nonlinear relationship between earnings management and managerial ownership. Correspondingly, managerial ownership is significantly and negatively associated with discretionary accruals at low and high levels, and positively associated with discretionary accruals at an intermediate level. Warfield, Wild, and Wild (1995) and Banderlipe (2009) find an inverse association between earnings management and managerial ownership.

In light of the existing evidence on the role of insiders' dominance in Pakistan,2 we expect the entrenchment hypothesis to hold strongly. Specifically, we expect that higher levels of managerial ownership give managers enough power to engage in earnings management in the form of bonuses, perks, and perquisites, which they are in a position to approve in their favor. Also, at higher levels of ownership, managers benefit equally from any improvement in operational profitability. Thus, owner-managers will have high incentive to derive all possible benefits from earnings management, such as obtaining external finance at a lower cost (Dechow, Sloan, \& Sweeney, 1996). Thus, we hypothesize that managerial ownership is positively associated with earnings management $(\mathrm{H} 2)$.

\subsection{Ownership Concentration and Earnings Management}

Shleifer and Vishny (1997) suggest that concentrated ownership has comparatively large advantages in developing countries, where property

2 Insider-controlled firms pay smaller dividends and usually have lower market share prices (Abdullah et al., 2011; Abdullah et al., 2012). 
rights are not well defined and protected by legal systems. La Porta, Lópezde-Silanes, Shleifer, and Vishny (1999) confirm this proposition: using the ownership concentration of the three largest shareholders of the biggest companies in countries around the world, they find that weak legal and institutional environments (laws and implementations) are linked with extremely concentrated company ownership.

Ownership concentration has two alternative effects on earnings management: alignment and entrenchment. According to the alignment impact, owners in a concentrated ownership structure have more incentive to monitor management because it costs less to do so than the anticipated advantages of their large stakes in the company. Ramsay and Blair (1993) suggest that concentrated ownership provides sufficient incentive to larger shareholders to monitor management. Their greater voting power allows them to affect the board-of-directors composition and its decisions (Persons, 2006).

The alignment impact decreases the controlling owner's incentive to expropriate firms for their personal benefit and to minimize earnings management practices in order to secure firms and their own future (Fan \& Wong, 2002). Consistent with this view, Roodposhti and Chashmi (2011), Alves (2012), and Abdoli (2011) find a significant and inverse association between earnings management practices and ownership concentration.

In contrast to this, Bebchuk (1994) and Stiglitz (1985) suggest that concentrated ownership might inversely influence the value of the firm, given the capacity of larger shareholders to exploit their dominant position at the cost of minority stockholders. Liu and Lu (2007) argue that the expropriation of minority shareholders by majority shareholders is directly associated with the extent of the latter's power in a firm. Their study finds a positive and significant association between the level of ownership concentration and earnings management practices.

Fan and Wong (2002) and Claessens, Djankov, and Lang (2000) provide empirical evidence that poor governance and lack of fair financial information disclosure are the main results of concentrated ownership in Asian corporations. Wang (2006) investigates the association between the presence of concentrated owners and the incidence of fraud, and finds that high ownership concentration is linked with a higher likelihood of fraud and a tendency to commit fraud. Choi, Jeon, and Park (2004) and Kim and Yoon (2008) also document a positive association between ownership concentration and earnings management. 
Given the corporate landscape in Pakistan where family businesses are common, concentrated ownership can imply the concentration of shares in the hands of a few family members-making the entrenchment hypothesis even more relevant. Thus, we hypothesize that there is a positive relationship between ownership concentration and earnings management $(\mathrm{H} 3)$.

\subsection{Audit Quality and Earnings Management}

Auditors play a key role in their clients' disclosure practices and procedures. Concerns regarding the quality of financial information and its association with the quality of the auditing process have grown with time, given the rising incidence of fraud in big businesses, failures, and litigation (Chambers, 1999; Tie, 1999). The auditing procedure serves as an investigation tool that can constrain managers' incentive to influence a firm's reported earnings (Wallace, 1980). Thus, auditing may reduce misreporting and mispricing in financial reporting and control managerial incentives and discretion with respect to earnings management.

DeAngelo (1981) characterizes audit quality as the mutual likelihood of reporting and detecting errors in a company's financial statements; this depends partially on the auditors' independence. External quality auditors are linked with financial reports featuring fewer earnings manipulation practices. Larger auditing firms have more incentive to preserve their reputation as well as more resources, which allows them to perform better auditing services than smaller auditors (Palmrose, 1988).

There are several proxies for measuring audit quality, including the size of the auditing firm (DeAngelo, 1981), the auditor's tenure with its clients (Johnson, Khurana, \& Reynolds, 2002), and the presence of an industry-specific auditor. However, there is sufficient evidence that the size of the auditing firm is a good proxy for audit quality (see Francis, Maydew, \& Sparks, 1999; Becker, DeFond, Jiambalvo, \& Subramanyam, 1998; Chia, Lapsley, \& Lee, 2007). Consistent with the literature, we hypothesize that there is a negative relationship between audit quality and earnings management $(\mathrm{H} 4)$.

\subsection{CEO Duality and Earnings Management}

When the same person serves as both a firm's CEO and board chairperson, we refer to this as CEO duality. Under Clause VI of the 
revised PCCG 2002,3 the SECP recommends a division of roles between board chairperson and CEO to avoid substantial concentration of control. However, given that 32 percent of the sample firms feature CEO duality, we consider it to be a significant variable.

Previous studies that have investigated CEO duality include Peng, Zhang, and Li (2007), and Dalton, Daily, Ellstrand, and Johnson (1998). The impartiality and quality of board control is generally perceived to suffer if the CEO is also the board chairperson. The centralization of authority in a firm may tempt the CEO to exercise excessive influence over the board, such as in managing meetings, setting board agendas, and controlling the stream of information made available to board members (Persons, 2006).

The literature puts forward two views on the role of CEO duality: the agency theory and stewardship theory (Abdul Rahman \& Haniffa, 2005). Under the agency theory, it is essential that these two roles are kept separate to ensure effectual board control over the firm's managers: this is provided through crosschecks to minimize any combative strategies by the CEO (Hashim \& Devi, 2008). When one person holds two key positions, they are more likely to follow policies that benefit them instead of all the firm's shareholders. Zulkafli, Abdul-Samad, and Ismail (2005) support this view and show that a division of power between the CEO and board chair permits effective monitoring via the firm's board.

Anderson, Mansi, and Reeb (2003) indicate that the reliability of information on accounting earnings is positively associated with the division of roles between board chair and CEO. Firms that commit fraud are more likely to have CEOs who also chair the board (CEO duality) (Chen, Firth, Gao, \& Rui, 2006). Worrell, Nemec, and Davidson (1997) document an inverse association between firm performance and CEO duality, which is consistent with the agency theory. Other studies, however, find no evidence of an association between these variables (see Daily \& Dalton, 1997; Peasnell, Pope, \& Young, 2000a; Bédard, Chtourou, \& Courteau, 2004; Kao \& Chen, 2004; Xie, Davidson, \& DaDalt, 2003; Rahman \& Ali, 2006).

Contrary to the above view, the stewardship theory states that combining the two roles of CEO and board chair enhances decisionmaking and enables strategic vision, allowing the chair/CEO to lead the

\footnotetext{
${ }^{3}$ The PCCG was revised in 2012 and is available at www.secp.gov.pk
} 
board toward the firm's goals and objectives with minimal intervention from the board. Given the problems of coordination, some boards favor CEO duality (Finkelstein \& D'Aveni, 1994). In addition, Haniffa and Cooke (2002) find that firms with CEO duality are subject to less interference in management, while depending on strong boards to provide adequate checks.

While the discussion above shows that studies have not reached a consensus on whether CEO duality reflects poor corporate governance and increases earnings management or vice versa, we have followed the literature and the PCCG in proposing that the roles of CEO and chair be separated. Thus, we hypothesize that CEO duality is positively associated with earnings management practices (H5).

\subsection{Board Size and Earnings Management}

Several studies show that larger boards have greater monitoring power over management activities. Some studies use board size to measure board expertise (Bacon, 1973; Herman, 1981), while Jensen (1993) argues that size is a value-relevant aspect of corporate boards. Smaller boards are believed to work more effectively than larger boards because they are easier to coordinate (Jensen, 1993). Yermack (1996) links better firm performance with smaller boards, specifically for large industrial corporations in the US, where firms with smaller boards have a higher market value.

Jensen (1993) and Lipton and Lorsch (1992) find that smaller boards are more effective than larger boards: the latter may be less efficient in carrying out oversight duties if the CEO tends to dominate board matters. Moreover, larger boards may be subject to a greater degree of protocol and etiquette, making it easier for the CEO to control the board (Jensen, 1993). Rahman and Ali (2006) and Chin, Firth, and Rui (2006) find a positive association between board size and earnings management.

The other view is that larger boards are able to contribute more time and effort to supervising management (Monks \& Minow, 1995). This argument is supported by Klein (2002), who suggests that larger boards are positively associated with effective monitoring, given their collective experience and ability to allocate the workload across several board members. Peasnell et al. (2000a), Bédard et al. (2004), and Xie et al. (2003) provide empirical evidence that earnings management practices are less common in firms with larger boards. Pearce and Zahra (1992) confirm that larger boards have a comparative advantage in terms of information and 
expertise over smaller boards. In most bankruptcy cases, for instance, firms are found to have smaller boards (Chaganti, Mahajan, \& Sharma, 1985).

Dalton, Daily, Johnson, and Ellstrand (1999) show that firm performance is positively associated with board size because larger boards have greater access to important resources such as financial support and expertise and more external linkages than smaller boards in executing company operations. Smaller boards are perceived as unable to detect or constrain earnings management $(\mathrm{Yu}, 2008)$ if dominated by large shareholders or management. Larger boards are better able to monitor the actions of top management (Zahra \& Pearce, 1989).

Larger boards with a more diverse range of academic and technical backgrounds, expertise, and perspectives on how to develop the quality of decision making are more likely to protect and represent shareholders' interests. They are thus less vulnerable to CEO dominance. Given this, we hypothesize that there is a negative relationship between board size and earnings management (H6).

\subsection{Control Variables}

Moses (1987) argues that larger firms are more visible, which means that they are expected to manage their earnings to reduce their visibility. Ashari, Koh, Tan, and Wong (1994), however, show that larger firms are subject to closer scrutiny by analysts and investors because there is more information available on them in the market. Sun and Rath (2009) investigate earnings management practices among Australian firms and find that most firms are involved in earnings management, of which the return on assets (ROA) and firm size are key determinants. Kim, Liu, and Rhee (2003) show that smaller firms engage in more earnings management practices than large firms. In view of this, we expect a negative relationship between firm size and earnings management.

We also include financial leverage as a control variable. Sweeney (1994) argues that managers use discretionary accruals to assure debt agreement requirements because highly leveraged companies have greater incentive to boost earnings. Becker et al. (1998) support this view and provide evidence that managers respond to debt contracting by strategically reporting discretionary accruals.

Dechow and Skinner (2000), however, argue that firms with a high leverage ratio are expected to report little boost in earnings. Similarly, Sveilby (2001) establishes that firms with a low financial leverage are 
expected to increase rather than decrease earnings. Chung and Kallapur (2003) examine the association between discretionary accruals and leverage, but fail to find a significant relationship between the two. In this study, we measure leverage as the ratio of total liabilities to total assets, denoted by LEVG.

We include ROA to control for long-term growth forecasting errors with respect to the incentive for earnings management (Kasznik, 1999; Dechow et al., 1995). Bartov, Gul, and Tsui (2000) argue that the incentive to engage in earnings management is greater among firms that are experiencing financial difficulty and performing poorly, i.e., in terms of ROA and cash flow. Several studies on corporate governance and earnings management include ROA as a control variable (see, for example, Ali, Salleh, \& Hassan, 2008; Rahman \& Ali, 2006; Chen, Cheng, \& Wang, 2010). We expect a positive association between ROA and earnings management.

Other control variables include the age of the firm (AGE), cumulative loss (LOSS), the book-to-market ratio (BM), growth in sales (GROWTH), and volatility of net income (VOL). We include all these in the study's model, given that they can potentially influence the firm's tendency to manage its earnings. For example, older firms, which are likely to have a higher cash flow, less operational risk, and a good reputation, are expected to avoid earnings management practices. Concerning the growth variable, the literature reveals that firms with high growth opportunities are often involved in earnings management in order to avail external finance at a lower cost. Similarly, firms with a volatile cash flow are expected to manage their earnings. Finally, Butler, Leone, and Willenborg (2004) suggest that discretionary accruals are higher for financially distressed firms. Therefore, we expect a positive relationship between discretionary accruals and existing accumulated loss.

\section{Data and Methodology}

This section presents an overview of the data, variables, and methodology used in the study.

\subsection{Sample and Data Sources}

Given that the SECP announced the PCCG in March 2002, the study's sample period spans 2003 to 2010. The sample consists of all firms listed on the KSE. However, the analysis does not include financial firms and firms for which there is incomplete data. Financial firms are uniquely 
regulated: their accruals behavior is different from that of nonfinancial firms (Klein, 2002) and is less easily captured by total accrual models (Peasnell, Pope, \& Young, 2000b).

Roodposhti and Chashmi (2011) observe that financial firms (including banks) are excluded because the industry is regulated and likely to have fundamentally different cash flows and accrual processes. Other studies provide evidence that commercial banks use loan loss provisions to manage their earnings (Beatty, Chamberlain, \& Magliolo, 1995). Klein (2002), for instance, excludes "53 banks (SIC codes: 6000 to 6199) and 36 insurance companies (SIC codes: 6300-6411) because it is difficult to define accruals and abnormal accruals for financial services firms." Bédard et al. (2004) exclude financial firms for similar reasons.

Table 1 describes the sample selection procedure. The sample is adjusted for outliers using a residual versus predicted scatter plot. In this analysis, the residuals are plotted on the y-axis and the predicted values on the x-axis; extreme values are identified and eliminated because they might distort the regression results and make generalization difficult. The data used has been collected from the annual reports of the companies listed on the KSE and from their respective websites.

Table 1: Sample selection details

\begin{tabular}{lr}
\hline Total number of firms listed on the KSE in Mar-Jul 2010 & 650 \\
Financial firms excluded & 146 \\
Firms with incomplete data & 132 \\
Number of firms included in the analysis & 372 \\
Firm-year observations available for calculation of accruals & 1,551 \\
Firm-year observations available in discretionary accruals in all models & 986 \\
\hline
\end{tabular}

Source: Authors' calculations.

\subsection{Calculation of the Dependent Variable}

The dependent variable in this study is discretionary accruals $(D A C)$. Accruals are defined as the difference between net income and cash flows from operations (Jones, 1991; Chen, Lin, \& Zhou, 2007). They can be further divided into discretionary (nonobligatory expenses) and nondiscretionary accruals (obligatory expenses). Discretionary accruals represent the modifications made to the cash flow by the firm's managers; nondiscretionary accruals are accounting-based adjustments to the firm's cash flow, which are directed by bodies that set accounting standards 
(Rao \& Dandale, 2008). Following Subramanyam (1996), Jones (1991), Shah et al. (2009), and Roodposhti and Chashmi (2011), we use discretionary accruals to estimate earnings management.

The first step in calculating discretionary accruals is to estimate total accruals, following which a particular model can be used to separate discretionary accruals from total accruals. Total accruals are defined as the difference between net income and the cash flow from operations scaled by the lagged total assets (Kasznik, 1999; Dechow et al., 1995).

$$
T A_{i t}=N I_{i t}-C F O_{i t}
$$

where $T A_{i t}$ refers to the total accruals of firm $i$ at time $t, N I_{i t}$ is the net income of firm $i$ at time $t$, and $C F O_{i t}$ refers to the cash flow from operations.

There are four well-known models used to separate accruals into their nondiscretionary and discretionary components. As explained in Section 1, we use all four models to calculate discretionary accruals for comparison and to determine the robustness of the results. These models are discussed below.

Prior to Jones (1991), nondiscretionary accruals were assumed to be constant over time. Jones introduced a model that accounted for the firm's changing economic circumstances in explaining total accruals. Her model is given below:

$$
T A_{i t} / A_{i t-1}=\alpha_{1}\left[1 / A_{i t-1}\right]+\alpha_{2}\left[\Delta R E V_{i t} / A_{i t-1}\right]+\alpha_{3}\left[P P E_{i t} / A_{i t-1}\right]+e_{i t}
$$

where $\triangle R E V_{i t}$ is the change in revenue for firm $i$ from time $t-1, A_{i t-1}$ refers to lagged total assets, and $P P E_{i t}$ denotes gross property, plant, and equipment for firm $i$ in time $t$.

The model includes $P P E$ and $\triangle R E V$ to control for changes in nondiscretionary accruals caused by the firm's changing macroeconomic circumstances. Changes in revenue can serve as an objective proxy for shifting economic conditions, while gross property, plant, and equipment captures the effect of nondiscretionary depreciation expenses on total accruals. All the variables are scaled by lagged total assets $\left(A_{i t-1}\right)$ to control for heteroskedasticity (see Kothari et al., 2005; Rajgopal \& Venkatachalam, 1997; Jones, Krishnan, \& Melendrez, 2007; Liu \& Lu, 2007). Equation (2) is then estimated for each year in a cross-sectional regression, where the regression residuals for each firm are calculated to determine DAC. 
Although Jones (1991) assumes that the firm's managers do not manage its revenues, i.e., revenues are nondiscretionary, there may be situations where managers choose to manipulate revenue figures. For example, Dechow et al. (1995) argue that, if managers decide to accrue the firm's revenues at the year's end where the cash has yet to be received, then the revenues will reflect an inflated amount in that year with a commensurate increase in account receivables. The authors adjust the Jones (1991) model to account for this managerial discretion over revenues. They deduct the change in account receivables $(\triangle R E C)$ from the change in revenues $(\triangle R E V)$. Their model is shown in equation (3):

$\left.T A_{i t} / A_{i t-1}=\alpha_{1}\left[1 / A_{i t-1}\right]+\alpha_{2}\left[\Delta R E V_{i t}-\Delta R E C_{i t}\right) / A_{i t-1}\right]+\alpha_{3}\left[P P E_{i t} / A_{i t-1}\right]+e_{i t}$

Kasznik (1999) adds the change in free cash flows ( $\triangle \mathrm{CFO})$ to the Dechow et al. (1995) model because evidence from Dechow (1994) suggests that $\triangle \mathrm{CFO}$ is negatively correlated with total accruals. Omitting $\Delta C F O$ from the accruals equation results in a higher estimation error. The Kasznik model is given below:

$\left.T A_{i t} / A_{i t-1}=\alpha_{1}\left[1 / A_{i t-1}\right]+\alpha_{2}\left[\Delta R E V_{i t}-\Delta R E C_{i t}\right) / A_{i t-1}\right]+\alpha_{3}\left[P P E_{i t} / A_{i t-1}\right]+$ $\alpha_{4}\left[\Delta C F O_{i t} / A_{i t-1}\right]+e_{i t}$

Kothari et al. (2005) employ a technique similar to Dechow et al. (1995) and add lagged ROA. They argue that the earnings management proxy would suffer from measurement error if one did not control for past performance. This is because accruals are associated with operating performance. They propose the following model:

$\left.T A_{i t} / A_{i t-1}=\alpha_{1}\left[1 / A_{i t-1}\right]+\alpha_{2}\left[\Delta R E V_{i t}-\Delta R E C_{i t}\right) / A_{i t-1}\right]+\alpha_{3}\left[P P E_{i t} / A_{i t-1}\right]+$ $\alpha_{3}\left[R O A_{i t} / A_{i t-1}\right]+e_{i t}$

\subsection{Model Specification and Tests}

Having constructed DAC, we follow the literature with respect to including other key variables and control variables in a regression model to assess the relationship between corporate governance and ownership structure and DAC (see, for example, Becker et al., 1998; Liu \& Lu, 2007; Ashbaugh-Skaife, Collins, Kinney, \& LaFond, 2008; Prawitt, Smith, \& Wood, 2009; Dhaliwal, Naiker, \& Navissi, 2010).

\subsubsection{Model for Estimating DAC}

The study's model is written as 
$D_{A C}=\alpha+\beta_{1}$ DIROWN $_{i t}+\beta_{2}$ INSTOWN $_{i t}+\beta_{3}$ OWNCON $_{i t}+\beta_{4} A U D Q+$ $\beta_{5}$ BSIZ $_{i t}+\beta_{6} C E O_{i t}+\beta_{7}$ BIGSOWN $_{i t}+\beta_{8}$ FSIZ $_{i t}+\beta_{9} L E V G_{i t}+\beta_{10} R_{0 A}+$ $\beta_{11} A G E_{i t}+\beta_{12} G R O W T H_{i t}+\beta_{13} M B_{i t}+\beta_{14}$ VOL $_{i t}+\beta_{15} L_{O S S}+e_{i t}$

where $D A C_{i t}$ refers to the discretionary accruals (as a proxy for earnings management) of firm $i$ at time $t$ while $e_{i t}$ is the error term. Table 2 defines the other explanatory and control variables in the model.

Table 2: Description of explanatory and control variables

\begin{tabular}{|c|c|c|}
\hline \multicolumn{2}{|c|}{ Variable } & Measured by \\
\hline $\begin{array}{l}\text { Ownership } \\
\text { concentration }\end{array}$ & $\mathrm{OWNCON}_{\mathrm{it}}$ & $\begin{array}{l}\text { Natural log of the number of firm shareholders } \\
\text { (Rozeff, 1982) }\end{array}$ \\
\hline $\begin{array}{l}\text { Institutional } \\
\text { ownership }\end{array}$ & INSTOWN $_{\text {it }}$ & $\begin{array}{l}\text { Percentage of common stock held by } \\
\text { institutions (Chashmi \& Roodposhti, 2011) }\end{array}$ \\
\hline $\begin{array}{l}\text { Managerial } \\
\text { ownership }\end{array}$ & DIROWN $_{\text {it }}$ & $\begin{array}{l}\text { Percentage of common stock held by } \\
\text { management (Saleh et al., 2005) }\end{array}$ \\
\hline Audit quality & AUDQ & $\begin{array}{l}\text { Dummy variable }=1 \text { if firm is audited by the } \\
\text { Big Four (PwC, Deloitte Touche Tohmatsu, } \\
\text { Ernst \& Young, KPMG) and } 0 \text { otherwise } \\
\text { (Siregar \& Utama, 2008) }\end{array}$ \\
\hline Board size & $\mathrm{BSIZ}_{\mathrm{it}}$ & Number of board members (Zhou \& Chen, 2004) \\
\hline CEO duality & $\mathrm{CEO}_{\mathrm{it}}$ & $\begin{array}{l}\text { Dummy variable }=1 \text { if CEO is also board } \\
\text { chairperson and } 0 \text { otherwise (Roodposhti \& } \\
\text { Chashmi, 2011) }\end{array}$ \\
\hline $\begin{array}{l}\text { Big } 5 \\
\text { ownership }\end{array}$ & BIG5OWNit & $\begin{array}{l}\text { Sum of ownership percentage of the five biggest } \\
\text { firm shareholders }\end{array}$ \\
\hline Firm size & FSIZ $_{\text {it }}$ & Log of total assets (Roodposhti \& Chashmi, 2011) \\
\hline Leverage & LEVG $_{\text {it }}$ & $\begin{array}{l}\text { Ratio of total liabilities to total assets } \\
\text { (Roodposhti \& Chashmi, 2011) }\end{array}$ \\
\hline $\begin{array}{l}\text { Return on } \\
\text { assets }\end{array}$ & $\mathrm{ROA}_{\mathrm{it}}$ & $\begin{array}{l}\text { Ratio of net income to total assets (Bekiris \& } \\
\text { Doukakis, 2011) }\end{array}$ \\
\hline Firm age & $\mathrm{AGE}_{\mathrm{it}}$ & $\begin{array}{l}\text { Difference between focal year and year of } \\
\text { incorporation }\end{array}$ \\
\hline Firm growth & GROWTH $_{\text {it }}$ & $\begin{array}{l}\text { Geometric mean of the annual percentage } \\
\text { increase in total sales calculated in a rolling } \\
\text { window of four years }\end{array}$ \\
\hline $\begin{array}{l}\text { Market-to-book } \\
\text { value }\end{array}$ & $\mathrm{MB}_{\text {it }}$ & $\begin{array}{l}\text { Ratio of market value per share to book value } \\
\text { per share }\end{array}$ \\
\hline Volatility & $\mathrm{VOL}_{\text {it }}$ & $\begin{array}{l}\text { Coefficient of the variation in net income in a } \\
\text { rolling window of four years }\end{array}$ \\
\hline Loss & LOSS $_{\mathrm{t}}$ & $\begin{array}{l}\text { Dummy variable }=1 \text { if the firm has accumulated } \\
\text { losses in balance sheet and } 0 \text { otherwise }\end{array}$ \\
\hline
\end{tabular}


Since we are using panel data, we must choose from among a pooled, fixed, or random effects model. Assuming that there are no systematic differences in earnings management practices across firms, years, and industries, pooled OLS is the preferred choice. However, the results of the Breusch-Pagan Lagrangian multiplier test (which helps choose between a random effects and pooled OLS model) show that pooled OLS cannot be used.

To choose between using a random and fixed effects model, we apply the Hausman specification test, the results of which favor the use of fixed effects (Table 3). Following the existing studies on earnings management, we include year and industry dummies to control for unobservable fixed effects in a given year or given industry while adjusting the errors for clustering at the firm level (see Badolato, Donelson, \& Ege, 2014; Dechow et al., 1995).

Table 3: Hausman specification test for fixed and random effects

\begin{tabular}{lcc}
\hline Model & $\mathbf{C h i}^{2}$ value & P-value \\
\hline Kothari et al. (2005) & 19.86 & 0.0306 \\
Kasznik (1999) & 32.90 & 0.0030 \\
Dechow et al. (1995) & 6.76 & 0.0700 \\
Jones (1991) & 12.78 & 0.0540 \\
\hline
\end{tabular}

Source: Authors' calculations.

Some of the independent variables and control variables are significantly correlated. In order to avoid over-specifying the model, we do not include all the variables in one regression; instead, we gradually add and drop variables in different models. Therefore, we estimate seven different regressions for each of the four accrual models discussed above.

\subsubsection{Endogeneity Test}

It is possible that some of the ownership variables and DAC are endogenously determined. For example, knowing that a firm will engage in earnings management through tactics that are beyond their control, institutional investors might choose not to invest in the firm or to simply leave once they discover instances of earnings management. In such cases, the causality can run from accrual management to institutional ownership or vice versa. 
We test for this possibility using the Wu-Hausman endogeneity test, the results of which (Table 4) show that institutional ownership is endogenous in relation to accruals. Therefore, we run a 2SLS regression to test the relationship between DAC and institutional ownership. The instruments selected for institutional ownership are ASMAT (fixed assets to total assets) and CASH (cash to total assets). These are selected on the basis of their high correlation with the INSTOWN variable, but nonsignificant correlation with the error term.

Table 4: Hausman-Wu test for endogeneity of institutional ownership

\begin{tabular}{lccc}
\hline Model & Degrees of freedom & F-test value & P-value \\
\hline Kothari et al. (2005) & $\mathrm{F}(1,896)$ & 12.96600 & 0.0003 \\
Kasznik (1999) & $\mathrm{F}(1,896)$ & 14.98060 & 0.0001 \\
Dechow et al. (1995) & $\mathrm{F}(1,896)$ & 9.97134 & 0.0016 \\
Jones (1991) & $\mathrm{F}(1,1,170)$ & 13.76600 & 0.0002 \\
\hline
\end{tabular}

Source: Authors' calculations.

\section{Analysis of Results}

This section examines the descriptive statistics and regression results.

\subsection{Descriptive Statistics}

Table 5 gives descriptive statistics for the dependent and explanatory variables. These are calculated only for those observations for which values for the dependent variables were available. The mean values of DAC using the Kothari, Kasznik, Dechow, and Jones models are $0.0035,0.0000,0.0254$, and 0.0253 , respectively. About 55 percent of the sample firms are audited by one of the Big Four auditors. Almost 31 percent have CEO duality, while 68 percent have separated the roles of CEO and chair. The mean board size is 7.98 , which is near the minimum requirement for the board of directors under Clause II, Section 174 of the Companies Ordinance 1984. 
Table 5: Descriptive statistics

\begin{tabular}{lcccrr}
\hline Variable & Observations & Mean & SD & \multicolumn{1}{c}{ Min. } & \multicolumn{1}{c}{ Max. } \\
\hline DAC_Kothari & 986 & 0.0035 & 0.1461 & -0.7200 & 0.7217 \\
DAC_Kasznik & 986 & 0.0000 & 0.1270 & -0.3555 & 1.8224 \\
DAC_Jones & 986 & 0.0253 & 0.2150 & -4.6217 & 1.8688 \\
DAC_Dechow & 986 & 0.0254 & 0.2014 & -3.4098 & 1.8735 \\
DIROWN & 967 & 0.2801 & 0.2771 & 0.0000 & 0.9775 \\
INSTOWN & 968 & 0.3637 & 0.2521 & 0.0000 & 0.9817 \\
BIG5OWN & 698 & 0.6267 & 0.2070 & 0.0000 & 0.9972 \\
BSIZE & 986 & 7.9899 & 1.5969 & 7.0000 & 15.0000 \\
CEO & 986 & 0.3093 & 0.4625 & 0.0000 & 1.0000 \\
AUDQ & 980 & 0.5500 & 0.4977 & 0.0000 & 1.0000 \\
CONC & 966 & 7.2110 & 1.2290 & 3.3262 & 10.9868 \\
ROA & 986 & 0.0971 & 0.1317 & -0.3004 & 1.9046 \\
AGE & 986 & 2.1552 & 0.8056 & 1.0000 & 3.0000 \\
GROWTH & 986 & 0.1976 & 0.3868 & -0.2758 & 11.2394 \\
MB & 929 & 1.3790 & 2.2779 & -13.0000 & 13.0000 \\
LEVG & 986 & 0.5452 & 0.2049 & 0.0017 & 0.9996 \\
VOL & 986 & 0.0579 & 0.0864 & 0.0014 & 1.1882 \\
FSIZE & 986 & 7.9058 & 1.5910 & 2.8622 & 12.2456 \\
\hline
\end{tabular}

Source: Authors' calculations.

On average, directors, their spouses, children, and other relatives hold 28 percent of common equity in firms while institutional shareholders hold almost 36.4 percent. Shah et al. (2009) report a similar level of institutional ownership for Pakistani firms. Of 426 firm-year observations, institutional investors hold stock equal to 50 percent or more; out of 423 firm-year observations, managers account for 50 percent or more ownership. The mean value of concentration is 7.24 while firms' average leverage ratio is 54.5 percent. The sample firms are profitable with a mean ROA of 9.7 percent. Their average size is $7.7 \mathrm{log}$ million.

The correlation coefficients are presented in Table 6, which shows that there is no serious multicollinearity problem: none of the coefficients among the explanatory variables is more than 0.7 . This is verified by the variance inflation factor, which should not exceed 10 . The correlation coefficients show that DAC is positively related to director ownership and audit quality in three models, and negatively correlated with institutional ownership, the ownership percentage of the five largest shareholders, and the concentration of ownership. 


\section{Table 6: Correlations matrix}

\begin{tabular}{|c|c|c|c|c|c|c|c|c|c|c|c|c|c|c|c|c|c|}
\hline & \multicolumn{4}{|c|}{ DAC } & DIROWN & \multirow[t]{2}{*}{ INSTOWN } & \multirow[t]{2}{*}{ BIG5OWN } & \multirow[t]{2}{*}{ BSIZE } & \multirow[t]{2}{*}{ CEO } & \multirow[t]{2}{*}{ AUDQ } & \multirow[t]{2}{*}{ CONC } & \multirow[t]{2}{*}{ ROA } & \multirow[t]{2}{*}{ AGE } & \multirow[t]{2}{*}{ GROW } & \multirow[t]{2}{*}{ MB } & \multirow[t]{2}{*}{ LEVG } & \multirow[t]{2}{*}{ VOL } \\
\hline Kothari & 1.00 & & & & & & & & & & & & & & & & \\
\hline Kasznik & 0.46 & 1.00 & & & & & & & & & & & & & & & \\
\hline Jones & 0.62 & 0.43 & 1.000 & & & & & & & & & & & & & & \\
\hline Dechow & 0.80 & 0.48 & 0.930 & 1.000 & & & & & & & & & & & & & \\
\hline DIROWN & 0.08 & -0.10 & 0.001 & 0.030 & 1.00 & & & & & & & & & & & & \\
\hline INSTOWN & -0.09 & 0.02 & -0.052 & -0.080 & -0.62 & 1.00 & & & & & & & & & & & \\
\hline BIG5OWN & -0.10 & 0.06 & -0.038 & -0.060 & -0.11 & 0.12 & 1.00 & & & & & & & & & & \\
\hline BSIZE & -0.06 & 0.08 & 0.010 & -0.017 & -0.24 & 0.25 & 0.03 & 1.000 & & & & & & & & & \\
\hline CEO & 0.00 & -0.04 & 0.010 & -0.001 & 0.10 & -0.11 & -0.04 & -0.200 & 1.00 & & & & & & & & \\
\hline AUDQ & -0.02 & 0.22 & 0.010 & 0.010 & -0.19 & 0.15 & 0.04 & 0.200 & -0.23 & 1.00 & & & & & & & \\
\hline CONC & -0.08 & 0.01 & -0.001 & -0.020 & -0.40 & 0.30 & -0.09 & 0.300 & -0.10 & 0.27 & 1.00 & & & & & & \\
\hline ROA & 0.11 & 0.77 & 0.151 & 0.190 & -0.15 & 0.04 & 0.03 & 0.120 & -0.08 & 0.30 & 0.10 & 1.00 & & & & & \\
\hline AGE & -0.01 & -0.02 & 0.040 & 0.010 & 0.05 & 0.01 & 0.10 & -0.001 & 0.101 & -0.01 & -0.01 & -0.01 & 1.00 & & & & \\
\hline GROWTH & 0.07 & 0.06 & 0.060 & 0.060 & -0.04 & 0.00 & 0.02 & 0.020 & -0.04 & 0.07 & -0.02 & 0.03 & -0.06 & 1.00 & & & \\
\hline MB & -0.06 & 0.25 & 0.050 & 0.030 & -0.24 & 0.09 & 0.10 & 0.145 & -0.01 & 0.26 & 0.16 & 0.34 & 0.07 & 0.00 & 1.00 & & \\
\hline LEVG & 0.01 & -0.17 & 0.080 & 0.040 & -0.01 & -0.10 & -0.03 & 0.120 & -0.00 & 0.01 & 0.08 & -0.16 & 0.04 & -0.05 & 0.15 & 1.00 & \\
\hline VOL & -0.00 & 0.02 & -0.001 & -0.010 & -0.00 & -0.05 & 0.04 & -0.010 & -0.11 & 0.07 & -0.02 & -0.00 & 0.04 & 0.00 & 0.02 & -0.06 & 1.00 \\
\hline FSIZE & -0.04 & 0.04 & 0.030 & 0.010 & -0.28 & 0.25 & -0.04 & 0.380 & -0.16 & 0.29 & 0.67 & 0.17 & -0.00 & 0.16 & 0.11 & 0.08 & -0.10 \\
\hline
\end{tabular}

Source: Authors' calculations. 


\subsection{Regression Results}

The results of the regression analysis are presented in Tables 7, 8, 9, and 10 using the accruals models of Kothari et al. (2005), Kasznik (1999), Dechow et al. (1995), and Jones (1991), respectively. DAC is regressed on several explanatory and control variables. The explanatory power of these models ranges from 10 percent (Jones model) to 68.7 percent (Kasznik model) as denoted by the $\mathrm{R}^{2}$ value. Overall, the regression models are highly significant. The low value of $\mathrm{R}^{2}$ in some of the models shows that only a small part of the variability of DAC is explained by the variability of the independent variables. However, this number is acceptable for any study employing DAC as a proxy for earnings management (Peasnell et al., 2000b).

In each table, columns (1) to (7) give different regression estimates; the ownership variables and highly correlated variables were entered separately in order to eliminate any over-identification. All the regressions include year and industry dummies. Apart from the institutional ownership regression, all the other models were estimated using fixed effects. The choice of a fixed effects model is based on the Hausman test results reported in Table 3. The test compares the coefficients of fixed and random effects models for systematic differences. If the coefficients of both models are systematically different, the null hypothesis of no difference is rejected. As shown in Table 3, the p-value of the Hausman test for all four models is below 10 percent, thus supporting the use of fixed effects.

As explained earlier, we find that institutional ownership is endogenously determined with DAC (see Table 4) and thus use the 2SLS technique to resolve the endogeneity issue. We use cash to total assets and fixed assets to total assets as instruments for institutional ownership in the first-stage 2SLS regression.

The results of the four models in Tables 7 to 10 show that director ownership has a positive impact on DAC. This relationship is statistically significant in three models and insignificant in the Jones (1999) model. DIROWN has a positive sign, which is in line with our hypothesis that, as the directors' ownership in a firm increases, they become more powerful and can influence corporate decisions more easily. This supports the entrenchment hypothesis as well as prior evidence from Pakistan that director ownership is associated with lower dividend payments (Abdullah et al., 2011) and lower firm performance (Abdullah et al., 2012). 
Table 7: Results for DAC regressed on ownership and control variables (Kothari et al. model)

\begin{tabular}{|c|c|c|c|c|c|c|c|}
\hline Variable & $\begin{array}{l}(1) \\
\text { DIR }\end{array}$ & $\begin{array}{c}(2) \\
\text { INST } \\
2 S L S \\
\end{array}$ & $\begin{array}{l}\text { (3) } \\
\text { BIG5 }\end{array}$ & $\begin{array}{c}(4) \\
\text { AUDQ }\end{array}$ & $\begin{array}{c}(5) \\
\text { BSIZE }\end{array}$ & $\begin{array}{l}\text { (6) } \\
\text { CEO }\end{array}$ & $\begin{array}{c}(7) \\
\text { CONC }\end{array}$ \\
\hline ROA & $\begin{array}{l}0.293^{* * *} \\
(0.075)\end{array}$ & $\begin{array}{l}0.249^{* * *} \\
(0.048)\end{array}$ & $\begin{array}{l}0.293^{* * *} \\
(0.082)\end{array}$ & $\begin{array}{l}0.279^{* * *} \\
(0.075)\end{array}$ & $\begin{array}{l}0.286^{* * *} \\
(0.075)\end{array}$ & $\begin{array}{l}0.285^{* * *} \\
(0.075)\end{array}$ & $\begin{array}{l}0.291^{* * *} \\
(0.074)\end{array}$ \\
\hline AGE & $\begin{array}{l}-0.011^{*} \\
(0.006)\end{array}$ & $\begin{array}{l}-0.000 \\
(0.007)\end{array}$ & $\begin{array}{l}-0.002 \\
(0.008)\end{array}$ & $\begin{array}{l}-0.008 \\
(0.006)\end{array}$ & $\begin{array}{l}-0.009 \\
(0.006)\end{array}$ & $\begin{array}{l}-0.009 \\
(0.006)\end{array}$ & $\begin{array}{l}-0.010 \\
(0.006)\end{array}$ \\
\hline GROWTH & $\begin{array}{l}0.030^{* * * *} \\
(0.010)\end{array}$ & $\begin{array}{l}0.021 \\
(0.015)\end{array}$ & $\begin{array}{l}0.028^{* * *} \\
(0.008)\end{array}$ & $\begin{array}{l}0.030^{* * *} \\
(0.011)\end{array}$ & $\begin{array}{l}0.029^{* * *} \\
(0.011)\end{array}$ & $\begin{array}{l}0.030^{* * *} \\
(0.011)\end{array}$ & $\begin{array}{l}0.029^{* * *} \\
(0.011)\end{array}$ \\
\hline MB & $\begin{array}{l}-0.004 \\
(0.003)\end{array}$ & $\begin{array}{l}0.000 \\
(0.003)\end{array}$ & $\begin{array}{l}-0.005 \\
(0.003)\end{array}$ & $\begin{array}{l}-0.004 \\
(0.003)\end{array}$ & $\begin{array}{l}-0.004 \\
(0.003)\end{array}$ & $\begin{array}{l}-0.004 \\
(0.003)\end{array}$ & $\begin{array}{l}-0.004 \\
(0.003)\end{array}$ \\
\hline LEVG & $\begin{array}{l}0.076^{* * *} \\
(0.024)\end{array}$ & $\begin{array}{l}-0.008 \\
(0.034)\end{array}$ & $\begin{array}{l}0.100^{* * * *} \\
(0.032)\end{array}$ & $\begin{array}{l}0.078^{* * * *} \\
(0.024)\end{array}$ & $\begin{array}{l}0.082^{* * * *} \\
(0.024)\end{array}$ & $\begin{array}{l}0.079^{* * *} \\
(0.024)\end{array}$ & $\begin{array}{l}0.078^{* * *} \\
(0.024)\end{array}$ \\
\hline FSIZE & $\begin{array}{l}0.001 \\
(0.005)\end{array}$ & $\begin{array}{l}0.008 \\
(0.006)\end{array}$ & $\begin{array}{l}-0.002 \\
(0.006)\end{array}$ & $\begin{array}{l}-0.001 \\
(0.005)\end{array}$ & $\begin{array}{l}0.001 \\
(0.004)\end{array}$ & $\begin{array}{l}0.000 \\
(0.004)\end{array}$ & \\
\hline VOL & $\begin{array}{l}0.037 \\
(0.053)\end{array}$ & $\begin{array}{l}-0.035 \\
(0.069)\end{array}$ & $\begin{array}{l}0.015 \\
(0.061)\end{array}$ & $\begin{array}{l}0.047 \\
(0.052)\end{array}$ & $\begin{array}{l}0.054 \\
(0.052)\end{array}$ & $\begin{array}{l}0.052 \\
(0.052)\end{array}$ & $\begin{array}{l}0.030 \\
(0.051)\end{array}$ \\
\hline LOSS & $\begin{array}{l}0.002 \\
(0.017)\end{array}$ & $\begin{array}{l}-0.005 \\
(0.018)\end{array}$ & $\begin{array}{l}0.005 \\
(0.019)\end{array}$ & $\begin{array}{l}0.007 \\
(0.017)\end{array}$ & $\begin{array}{l}0.006 \\
(0.016)\end{array}$ & $\begin{array}{l}0.006 \\
(0.016)\end{array}$ & $\begin{array}{l}0.003 \\
(0.016)\end{array}$ \\
\hline DIROWN & $\begin{array}{l}0.035^{* *} \\
(0.016)\end{array}$ & & & & & & \\
\hline INSTOWN & & $\begin{array}{l}-0.397^{* * *} \\
(0.121)\end{array}$ & & & & & \\
\hline BIG5OWN & & & $\begin{array}{l}-0.047 \\
(0.030)\end{array}$ & & & & \\
\hline AUDQ & & & & $\begin{array}{l}0.006 \\
(0.010)\end{array}$ & & & \\
\hline BSIZE & & & & & $\begin{array}{l}-0.004 \\
(0.003)\end{array}$ & & \\
\hline CEO & & & & & & $\begin{array}{l}0.002 \\
(0.009)\end{array}$ & \\
\hline CONC & & & & & & & $\begin{array}{l}-0.004 \\
(0.004)\end{array}$ \\
\hline Constant & $\begin{array}{l}-0.074^{*} \\
(0.044)\end{array}$ & $\begin{array}{l}0.068^{*} \\
(0.040)\end{array}$ & $\begin{array}{l}-0.061 \\
(0.056)\end{array}$ & $\begin{array}{l}-0.058 \\
(0.042)\end{array}$ & $\begin{array}{l}-0.045 \\
(0.047)\end{array}$ & $\begin{array}{l}-0.065 \\
(0.043)\end{array}$ & $\begin{array}{l}-0.038 \\
(0.042)\end{array}$ \\
\hline Observations & 908 & 907 & 655 & 921 & 927 & 927 & 909 \\
\hline $\mathrm{R}^{2}$ & 0.155 & & 0.173 & 0.143 & 0.145 & 0.144 & 0.151 \\
\hline $\begin{array}{l}\text { Industry and } \\
\text { year dummies }\end{array}$ & Yes & & Yes & Yes & Yes & Yes & Yes \\
\hline
\end{tabular}

Note: Robust standard errors adjusted for clustering at the firm level are reported in parentheses beneath the coefficients of the explanatory variables. Statistical significance is denoted by ${ }^{* * *}, * *$, and $*$ at 1,5 , and 10 percent, respectively.

Source: Authors' calculations. 
The next most important finding is the negative association between institutional ownership and DAC. The coefficient of INSTOWN is negative and statistically significant at the 1 percent level in all four models. This finding supports our hypothesis (H1) that institutional investors play an important role in monitoring the activities of managers, using their knowledge and dominant ownership stake in doing so. This finding is in line with the literature on the role of institutional investors in Pakistan. For example, Abdullah et al. (2011) find that institutional investors in Pakistan use their power to force entrenched managers to pay out dividends.

Of the other ownership variables, none is statistically significant in any model except for ownership concentration (CONC), which is statistically significant and negatively related to DAC only in the Kasznik (1999) model in Table 8. The ownership concentration of the five largest shareholders (BIG5OWN) carries the expected negative sign in three models, but is statistically insignificant. One reason for its nonsignificance may be that the largest shareholders play an effective role in monitoring only when they are external. If they are part of the management or family group, then their role is similar to that of entrenched managers. Since our data does not allow us to differentiate between external and internal block holders, the variable BIG5OWN may have mixed these two roles.

The coefficients of the other ownership variables-audit quality (AUDQ), board size (BSIZE), and CEO duality (CEO)-are all insignificant. This may relate to managers' control over the selection of board members and decisions, in turn leading to ineffective monitoring (Kosnik, 1987) and/or the lack of fair disclosure by the corporation.

Among the control variables, ROA has a positive and statistically significant coefficient in all the models. This implies that firms with higher earnings manage their earnings to a larger degree. Older firms are seen to engage less in earnings management. The coefficient of AGE is negative in most models and statistically significant. Older firms take on less risk and enjoy a more sound reputation, which helps them avail external finance more easily and at a lower cost. This, in turn, makes earnings management a less attractive option for them. 
Table 8: Results for DAC regressed on ownership and control variables (Kasznik model)

\begin{tabular}{|c|c|c|c|c|c|c|c|}
\hline Variable & $\begin{array}{l}\text { (1) } \\
\text { DIR }\end{array}$ & $\begin{array}{c}\text { (2) } \\
\text { INST } \\
\text { 2SLS }\end{array}$ & $\begin{array}{l}\text { (3) } \\
\text { BIG5 }\end{array}$ & $\begin{array}{c}(4) \\
\text { AUDQ }\end{array}$ & $\begin{array}{c}\text { (5) } \\
\text { BSIZE }\end{array}$ & $\begin{array}{l}\text { (6) } \\
\text { CEO }\end{array}$ & $\begin{array}{c}(7) \\
\text { CONC }\end{array}$ \\
\hline ROA & $\begin{array}{l}0.745^{* * *} \\
(0.035)\end{array}$ & $\begin{array}{l}0.841^{* * *} \\
(0.021)\end{array}$ & $\begin{array}{l}0.745^{* * *} \\
(0.041)\end{array}$ & $\begin{array}{l}0.739 * * * \\
(0.035)\end{array}$ & $\begin{array}{l}0.744^{* * *} \\
(0.035)\end{array}$ & $\begin{array}{l}0.744^{* * *} \\
(0.035)\end{array}$ & $\begin{array}{l}0.736^{* * *} \\
(0.035)\end{array}$ \\
\hline AGE & $\begin{array}{l}-0.005^{* *} \\
(0.003)\end{array}$ & $\begin{array}{l}0.000 \\
(0.003)\end{array}$ & $\begin{array}{l}-0.004 \\
(0.003)\end{array}$ & $\begin{array}{l}-0.005^{*} \\
(0.003)\end{array}$ & $\begin{array}{l}-0.005^{*} \\
(0.003)\end{array}$ & $\begin{array}{l}-0.005^{*} \\
(0.003)\end{array}$ & $\begin{array}{l}-0.006^{* *} \\
(0.003)\end{array}$ \\
\hline GROWTH & $\begin{array}{l}0.011 \\
(0.008)\end{array}$ & $\begin{array}{l}0.006 \\
(0.007)\end{array}$ & $\begin{array}{l}0.009 \\
(0.007)\end{array}$ & $\begin{array}{l}0.011 \\
(0.008)\end{array}$ & $\begin{array}{l}0.010 \\
(0.008)\end{array}$ & $\begin{array}{l}0.010 \\
(0.008)\end{array}$ & $\begin{array}{l}0.008 \\
(0.007)\end{array}$ \\
\hline MB & $\begin{array}{l}0.000 \\
(0.001)\end{array}$ & $\begin{array}{l}0.002 \\
(0.001)\end{array}$ & $\begin{array}{l}-0.000 \\
(0.001)\end{array}$ & $\begin{array}{l}-0.000 \\
(0.001)\end{array}$ & $\begin{array}{l}-0.000 \\
(0.001)\end{array}$ & $\begin{array}{l}-0.000 \\
(0.001)\end{array}$ & $\begin{array}{l}-0.000 \\
(0.001)\end{array}$ \\
\hline LEVG & $\begin{array}{l}0.011 \\
(0.011)\end{array}$ & $\begin{array}{l}-0.034^{* *} \\
(0.015)\end{array}$ & $\begin{array}{l}0.020 \\
(0.014)\end{array}$ & $\begin{array}{l}0.013 \\
(0.012)\end{array}$ & $\begin{array}{l}0.013 \\
(0.012)\end{array}$ & $\begin{array}{l}0.012 \\
(0.012)\end{array}$ & $\begin{array}{l}0.010 \\
(0.011)\end{array}$ \\
\hline FSIZE & $\begin{array}{l}-0.005^{* *} \\
(0.002)\end{array}$ & $\begin{array}{l}0.002 \\
(0.003)\end{array}$ & $\begin{array}{l}-0.005^{* *} \\
(0.002)\end{array}$ & $\begin{array}{l}-0.004 \\
(0.003)\end{array}$ & $\begin{array}{l}-0.003 \\
(0.003)\end{array}$ & $\begin{array}{l}-0.003 \\
(0.003)\end{array}$ & \\
\hline VOL & $\begin{array}{l}0.049^{* *} \\
(0.019)\end{array}$ & $\begin{array}{l}0.090^{* * *} \\
(0.031)\end{array}$ & $\begin{array}{l}0.080^{* * *} \\
(0.029)\end{array}$ & $\begin{array}{l}0.058^{* * *} \\
(0.022)\end{array}$ & $\begin{array}{l}0.061^{* * *} \\
(0.023)\end{array}$ & $\begin{array}{l}0.061^{* * * *} \\
(0.022)\end{array}$ & $\begin{array}{l}0.055^{* *} \\
(0.021)\end{array}$ \\
\hline LOSS & $\begin{array}{l}-0.007 \\
(0.006)\end{array}$ & $\begin{array}{l}0.012 \\
(0.008)\end{array}$ & $\begin{array}{l}-0.003 \\
(0.007)\end{array}$ & $\begin{array}{l}-0.003 \\
(0.006)\end{array}$ & $\begin{array}{l}-0.004 \\
(0.006)\end{array}$ & $\begin{array}{l}-0.004 \\
(0.006)\end{array}$ & $\begin{array}{l}-0.002 \\
(0.006)\end{array}$ \\
\hline DIROWN & $\begin{array}{l}0.012^{*} \\
(0.007)\end{array}$ & & & & & & \\
\hline INSTOWN & & $\begin{array}{l}-0.175^{* * *} \\
(0.054)\end{array}$ & & & & & \\
\hline BIG5OWN & & & $\begin{array}{l}0.007 \\
(0.011)\end{array}$ & & & & \\
\hline AUDQ & & & & $\begin{array}{l}0.006 \\
(0.004)\end{array}$ & & & \\
\hline BSIZE & & & & & $\begin{array}{l}-0.000 \\
(0.002)\end{array}$ & & \\
\hline CEO & & & & & & $\begin{array}{l}0.002 \\
(0.004)\end{array}$ & \\
\hline CONC & & & & & & & $\begin{array}{l}-0.005^{* *} \\
(0.002)\end{array}$ \\
\hline Constant & $\begin{array}{l}-0.048^{* * *} \\
(0.019)\end{array}$ & $\begin{array}{l}-0.021 \\
(0.018)\end{array}$ & $\begin{array}{l}-0.065^{* * *} \\
(0.025)\end{array}$ & $\begin{array}{l}-0.055^{* *} \\
(0.023)\end{array}$ & $\begin{array}{l}-0.057^{* *} \\
(0.022)\end{array}$ & $\begin{array}{l}-0.060^{* * * *} \\
(0.022)\end{array}$ & $\begin{array}{l}-0.049^{* * * *} \\
(0.018)\end{array}$ \\
\hline Observations & 908 & 907 & 655 & 921 & 927 & 927 & 909 \\
\hline $\mathrm{R}^{2}$ & 0.659 & 0.665 & 0.687 & 0.645 & 0.644 & 0.644 & 0.654 \\
\hline $\begin{array}{l}\text { Industry and year } \\
\text { dummies }\end{array}$ & Yes & & Yes & Yes & Yes & Yes & Yes \\
\hline
\end{tabular}

Note: Robust standard errors adjusted for clustering at the firm level are reported in parentheses beneath the coefficients of the explanatory variables. Statistical significance is denoted by ${ }^{* * *}, * *$, and ${ }^{*}$ at 1,5 , and 10 percent, respectively.

Source: Authors' calculations. 
Table 9: Results for DAC regressed on ownership and control variables (Dechow et al. model)

\begin{tabular}{|c|c|c|c|c|c|c|c|}
\hline Variable & $\begin{array}{l}(1) \\
\text { DIR }\end{array}$ & $\begin{array}{c}\text { (2) } \\
\text { INST } \\
\text { 2SLS }\end{array}$ & $\begin{array}{l}\text { (3) } \\
\text { BIG5 }\end{array}$ & $\begin{array}{c}\text { (4) } \\
\text { AUDQ }\end{array}$ & $\begin{array}{c}\text { (5) } \\
\text { BSIZE }\end{array}$ & $\begin{array}{l}\text { (6) } \\
\text { CEO }\end{array}$ & $\begin{array}{c}(7) \\
\text { CONC }\end{array}$ \\
\hline ROA & $\begin{array}{l}0.440^{* * *} \\
(0.079)\end{array}$ & $\begin{array}{l}0.705^{* * *} \\
(0.059)\end{array}$ & $\begin{array}{l}0.400^{* * *} \\
(0.093)\end{array}$ & $\begin{array}{l}0.416^{* * *} \\
(0.080)\end{array}$ & $\begin{array}{l}0.426^{* * *} \\
(0.083)\end{array}$ & $\begin{array}{l}0.424^{* * *} \\
(0.082)\end{array}$ & $\begin{array}{l}0.446^{* * *} \\
(0.076)\end{array}$ \\
\hline AGE & $\begin{array}{l}-0.012^{*} \\
(0.007)\end{array}$ & $\begin{array}{l}0.006 \\
(0.009)\end{array}$ & $\begin{array}{l}-0.006 \\
(0.009)\end{array}$ & $\begin{array}{l}-0.009 \\
(0.007)\end{array}$ & $\begin{array}{l}-0.010 \\
(0.007)\end{array}$ & $\begin{array}{l}-0.010 \\
(0.007)\end{array}$ & $\begin{array}{l}-0.009 \\
(0.006)\end{array}$ \\
\hline GROWTH & $\begin{array}{l}0.031^{* * *} \\
(0.011)\end{array}$ & $\begin{array}{l}0.018 \\
(0.018)\end{array}$ & $\begin{array}{l}0.032^{* * *} \\
(0.012)\end{array}$ & $\begin{array}{l}0.031^{* * *} \\
(0.011)\end{array}$ & $\begin{array}{l}0.031^{* *} \\
(0.012)\end{array}$ & $\begin{array}{l}0.031^{* * *} \\
(0.011)\end{array}$ & $\begin{array}{l}0.034^{* *} \\
(0.015)\end{array}$ \\
\hline MB & $\begin{array}{l}-0.002 \\
(0.003)\end{array}$ & $\begin{array}{l}0.001 \\
(0.004)\end{array}$ & $\begin{array}{l}-0.004 \\
(0.003)\end{array}$ & $\begin{array}{l}-0.003 \\
(0.003)\end{array}$ & $\begin{array}{l}-0.003 \\
(0.003)\end{array}$ & $\begin{array}{l}-0.003 \\
(0.003)\end{array}$ & $\begin{array}{l}-0.003 \\
(0.003)\end{array}$ \\
\hline LEVG & $\begin{array}{l}0.060^{*} \\
(0.034)\end{array}$ & $\begin{array}{l}0.056 \\
(0.043)\end{array}$ & $\begin{array}{l}0.100^{* *} \\
(0.048)\end{array}$ & $\begin{array}{l}0.060^{*} \\
(0.032)\end{array}$ & $\begin{array}{l}0.061^{* *} \\
(0.030)\end{array}$ & $\begin{array}{l}0.061^{*} \\
(0.032)\end{array}$ & $\begin{array}{l}0.062^{*} \\
(0.034)\end{array}$ \\
\hline FSIZE & $\begin{array}{l}0.008 \\
(0.009)\end{array}$ & $\begin{array}{l}0.010 \\
(0.007)\end{array}$ & $\begin{array}{l}0.010 \\
(0.013)\end{array}$ & $\begin{array}{l}0.008 \\
(0.010)\end{array}$ & $\begin{array}{l}0.010 \\
(0.008)\end{array}$ & $\begin{array}{l}0.010 \\
(0.009)\end{array}$ & \\
\hline VOL & $\begin{array}{l}-0.032 \\
(0.051)\end{array}$ & $\begin{array}{l}0.116 \\
(0.086)\end{array}$ & $\begin{array}{l}-0.034 \\
(0.070)\end{array}$ & $\begin{array}{l}-0.016 \\
(0.054)\end{array}$ & $\begin{array}{l}-0.011 \\
(0.055)\end{array}$ & $\begin{array}{l}-0.011 \\
(0.054)\end{array}$ & $\begin{array}{l}-0.055 \\
(0.059)\end{array}$ \\
\hline LOSS & $\begin{array}{l}0.014 \\
(0.021)\end{array}$ & $\begin{array}{l}0.017 \\
(0.022)\end{array}$ & $\begin{array}{l}0.031 \\
(0.026)\end{array}$ & $\begin{array}{l}0.021 \\
(0.020)\end{array}$ & $\begin{array}{l}0.019 \\
(0.020)\end{array}$ & $\begin{array}{l}0.019 \\
(0.020)\end{array}$ & $\begin{array}{l}0.009 \\
(0.018)\end{array}$ \\
\hline DIROWN & $\begin{array}{l}0.033^{* *} \\
(0.016)\end{array}$ & & & & & & \\
\hline INSTOWN & & $\begin{array}{l}-0.437^{* * *} \\
(0.151)\end{array}$ & & & & & \\
\hline BIG5OWN & & & $\begin{array}{l}-0.014 \\
(0.033)\end{array}$ & & & & \\
\hline AUDQ & & & & $\begin{array}{l}0.011 \\
(0.012)\end{array}$ & & & \\
\hline BSIZE & & & & & $\begin{array}{l}0.000 \\
(0.006)\end{array}$ & & \\
\hline CEO & & & & & & $\begin{array}{l}-0.004 \\
(0.009)\end{array}$ & \\
\hline CONC & & & & & & & $\begin{array}{l}-0.002 \\
(0.005)\end{array}$ \\
\hline Constant & $\begin{array}{l}-0.141^{*} \\
(0.074)\end{array}$ & $\begin{array}{l}-0.020 \\
(0.049)\end{array}$ & $\begin{array}{l}-0.165 \\
(0.107)\end{array}$ & $\begin{array}{l}-0.139^{*} \\
(0.072)\end{array}$ & $\begin{array}{l}-0.147 \\
(0.091)\end{array}$ & $\begin{array}{l}-0.144^{* *} \\
(0.069)\end{array}$ & $\begin{array}{l}-0.063 \\
(0.047)\end{array}$ \\
\hline $\begin{array}{l}\text { Observations } \\
\mathrm{R}^{2}\end{array}$ & $\begin{array}{l}908 \\
0.156\end{array}$ & 907 & $\begin{array}{l}655 \\
0.158\end{array}$ & $\begin{array}{l}921 \\
0.145\end{array}$ & $\begin{array}{l}927 \\
0.146\end{array}$ & $\begin{array}{l}927 \\
0.146\end{array}$ & $\begin{array}{l}909 \\
0.150\end{array}$ \\
\hline $\begin{array}{l}\text { Industry and year } \\
\text { dummies }\end{array}$ & Yes & & Yes & Yes & Yes & Yes & Yes \\
\hline
\end{tabular}

Note: Robust standard errors adjusted for clustering at the firm level are reported in parentheses beneath the coefficients of the explanatory variables. Statistical significance is denoted by ${ }^{* * *}, * *$, and ${ }^{*}$ at 1,5 , and 10 percent, respectively.

Source: Authors' calculations. 
Table 10: Results for DAC regressed on ownership and control variables (Jones model)

\begin{tabular}{|c|c|c|c|c|c|c|c|}
\hline Variable & $\begin{array}{l}(1) \\
\text { DIR }\end{array}$ & $\begin{array}{c}\text { (2) } \\
\text { INST } \\
\text { 2SLS }\end{array}$ & $\begin{array}{c}(3) \\
\text { BIG5 }\end{array}$ & $\begin{array}{c}(4) \\
\text { AUDQ }\end{array}$ & $\begin{array}{c}\text { (5) } \\
\text { BSIZE }\end{array}$ & $\begin{array}{l}\text { (6) } \\
\text { CEO }\end{array}$ & $\begin{array}{c}(7) \\
\text { CONC }\end{array}$ \\
\hline ROA & $\begin{array}{l}0.580^{* * *} \\
(0.103)\end{array}$ & $\begin{array}{l}0.733^{* * *} \\
(0.056)\end{array}$ & $\begin{array}{l}0.324^{* * *} \\
(0.075)\end{array}$ & $\begin{array}{l}0.579^{* * *} \\
(0.105)\end{array}$ & $\begin{array}{l}.572^{* * *} \\
(0.106)\end{array}$ & $\begin{array}{l}0.577^{* * *} \\
(0.104)\end{array}$ & $\begin{array}{l}0.587^{* * *} \\
(0.099)\end{array}$ \\
\hline AGE & $\begin{array}{l}-0.001 \\
(0.006)\end{array}$ & $\begin{array}{l}0.021^{* *} \\
(0.009)\end{array}$ & $\begin{array}{l}-0.004 \\
(0.008)\end{array}$ & $\begin{array}{l}0.001 \\
(0.006)\end{array}$ & $\begin{array}{l}-0.001 \\
(0.006)\end{array}$ & $\begin{array}{l}-0.000 \\
(0.006)\end{array}$ & $\begin{array}{l}0.002 \\
(0.006)\end{array}$ \\
\hline GROWTH & $\begin{array}{l}0.011 \\
(0.012)\end{array}$ & $\begin{array}{l}-0.004 \\
(0.013)\end{array}$ & $\begin{array}{l}0.011 \\
(0.012)\end{array}$ & $\begin{array}{l}0.010 \\
(0.012)\end{array}$ & $\begin{array}{l}0.012 \\
(0.012)\end{array}$ & $\begin{array}{l}0.011 \\
(0.012)\end{array}$ & $\begin{array}{l}0.012 \\
(0.014)\end{array}$ \\
\hline MB & $\begin{array}{l}-0.005^{*} \\
(0.003)\end{array}$ & $\begin{array}{l}0.001 \\
(0.004)\end{array}$ & $\begin{array}{l}-0.003 \\
(0.003)\end{array}$ & $\begin{array}{l}-0.006^{*} \\
(0.003)\end{array}$ & $\begin{array}{l}-0.006^{*} \\
(0.003)\end{array}$ & $\begin{array}{l}-0.006^{*} \\
(0.003)\end{array}$ & $\begin{array}{l}-0.005^{*} \\
(0.003)\end{array}$ \\
\hline LEVG & $\begin{array}{l}0.086^{* *} \\
(0.037)\end{array}$ & $\begin{array}{l}0.052 \\
(0.043)\end{array}$ & $\begin{array}{l}0.079^{*} \\
(0.044)\end{array}$ & $\begin{array}{l}0.081^{* *} \\
(0.034)\end{array}$ & $\begin{array}{l}0.078^{* *} \\
(0.032)\end{array}$ & $\begin{array}{l}0.082^{* *} \\
(0.034)\end{array}$ & $\begin{array}{l}0.090^{* *} \\
(0.037)\end{array}$ \\
\hline FSIZE & $\begin{array}{l}0.012 \\
(0.012)\end{array}$ & $\begin{array}{l}0.014^{* *} \\
(0.007)\end{array}$ & $\begin{array}{l}0.015 \\
(0.015)\end{array}$ & $\begin{array}{l}0.011 \\
(0.012)\end{array}$ & $\begin{array}{l}0.010 \\
(0.009)\end{array}$ & $\begin{array}{l}0.011 \\
(0.011)\end{array}$ & \\
\hline VOL & $\begin{array}{l}0.019 \\
(0.050)\end{array}$ & $\begin{array}{l}0.073 \\
(0.081)\end{array}$ & $\begin{array}{l}-0.002 \\
(0.063)\end{array}$ & $\begin{array}{l}0.027 \\
(0.050)\end{array}$ & $\begin{array}{l}0.021 \\
(0.054)\end{array}$ & $\begin{array}{l}0.028 \\
(0.051)\end{array}$ & $\begin{array}{l}-0.013 \\
(0.063)\end{array}$ \\
\hline LOSS & $\begin{array}{l}0.012 \\
(0.026)\end{array}$ & $\begin{array}{l}0.003 \\
(0.021)\end{array}$ & $\begin{array}{l}0.033 \\
(0.027)\end{array}$ & $\begin{array}{l}0.014 \\
(0.023)\end{array}$ & $\begin{array}{l}0.014 \\
(0.023)\end{array}$ & $\begin{array}{l}0.014 \\
(0.024)\end{array}$ & $\begin{array}{l}0.004 \\
(0.018)\end{array}$ \\
\hline DIROWN & $\begin{array}{l}0.026 \\
(0.018)\end{array}$ & & & & & & \\
\hline INSTOWN & & $\begin{array}{l}-0.510^{* * *} \\
(0.156)\end{array}$ & & & & & \\
\hline BIG5OWN & & & $\begin{array}{l}-0.010 \\
(0.026)\end{array}$ & & & & \\
\hline AUDQ & & & & $\begin{array}{l}-0.005 \\
(0.014)\end{array}$ & & & \\
\hline BSIZE & & & & & $\begin{array}{l}0.006 \\
(0.007)\end{array}$ & & \\
\hline CEO & & & & & & $\begin{array}{l}0.008 \\
(0.009)\end{array}$ & \\
\hline CONC & & & & & & & $\begin{array}{l}-0.006 \\
(0.007)\end{array}$ \\
\hline Constant & $\begin{array}{l}-0.196^{* *} \\
(0.093)\end{array}$ & $\begin{array}{l}-0.052 \\
(0.046)\end{array}$ & $\begin{array}{l}-0.203^{*} \\
(0.121)\end{array}$ & $\begin{array}{l}-0.184^{* *} \\
(0.085)\end{array}$ & $\begin{array}{l}-0.215^{*} \\
(0.111)\end{array}$ & $\begin{array}{l}-0.190^{* *} \\
(0.082)\end{array}$ & $\begin{array}{l}-0.068 \\
(0.052)\end{array}$ \\
\hline Observations & 1,184 & 1,181 & 826 & 1,202 & 1,210 & 1,210 & 1,188 \\
\hline $\mathrm{R}^{2}$ & 0.153 & & 0.100 & 0.146 & 0.148 & 0.147 & 0.146 \\
\hline $\begin{array}{l}\text { Industry and year } \\
\text { dummies }\end{array}$ & Yes & & Yes & Yes & Yes & Yes & Yes \\
\hline
\end{tabular}

Note: Robust standard errors adjusted for clustering at the firm level are reported in parentheses beneath the coefficients of the explanatory variables. Statistical significance is denoted by ${ }^{* * *},{ }^{* *}$, and ${ }^{*}$ at 1,5 , and 10 percent, respectively.

Source: Authors' calculations. 
Similarly, the variable GROWTH has a positive coefficient and is statistically significant. This confirms the argument above that younger and growing firms are more likely to manage their earnings. LEVG is positively associated with earnings management in almost all the models and is statistically significant in most cases. This indicates that firms with higher debt financing are more likely to be involved in earnings management, which helps them reduce the volatility of their reported net incomes and, in turn, renew their loans.

The other control variables are either insignificant or have different coefficient signs in different models. For example, firm size (FSIZE) has a negative coefficient in the Kasznik model (Table 8), but a positive and insignificant coefficient in the Dechow (Table 9) and Jones models (Table 10). None of the other control variables have statistically significant coefficients.

\subsection{Robustness Checks}

To determine the robustness of the results, we start by calculating the average DAC for all four models and then check if the managerial and institutional ownership variables still yield results that are consistent with the baseline results. Next, we test for the nonmonotonic influence of managerial ownership on DAC and also whether the global financial crisis of 2008 had any major impact on the regression results (see Table 11).

Teshima and Shuto (2008) provide theoretical and empirical evidence in support of the nonmonotonic influence of managerial ownership on DAC. They show that, at lower and higher levels of managerial ownership, the alignment of interest between managers and shareholders is more pronounced, resulting in lower scope for earnings management. At an intermediate level of managerial ownership, the entrenchment effect (see Section 2) is more dominant, which results in greater earnings management. The authors add quadratic and cubic terms of the managerial ownership percentage to the DAC regressions.

To test for this possibility, we use the average of the accruals calculated using the four models: not reporting the results for each model individually saves space. The average accruals are then regressed on the director ownership percentage, its squared term, and cubic term. These terms are added gradually to different regressions, the results of which are reported in columns (1), (2), and (3) in Table 11.4

\footnotetext{
${ }^{4}$ This methodology is borrowed from Teshima and Shuto (2008).
} 
Table 11: Robustness checks using average accruals

\begin{tabular}{|c|c|c|c|c|c|}
\hline Variable & $\begin{array}{c}\text { (1) } \\
\text { Average } \\
\text { accruals }\end{array}$ & $\begin{array}{c}\text { (2) } \\
\text { DIROWN2 }\end{array}$ & $\begin{array}{c}\text { (3) } \\
\text { DIROWN3 }\end{array}$ & $\begin{array}{c}\text { (4) } \\
\text { INST }\end{array}$ & $\begin{array}{l}\text { (5) } \\
\text { Crisis }\end{array}$ \\
\hline ROA & $\begin{array}{l}0.454^{* * *} \\
(0.062)\end{array}$ & $\begin{array}{l}0.456^{* * *} \\
(0.062)\end{array}$ & $\begin{array}{l}0.456^{* * *} \\
(0.062)\end{array}$ & $\begin{array}{l}0.614^{* * *} \\
(0.044)\end{array}$ & $\begin{array}{l}0.454^{* * *} \\
(0.060)\end{array}$ \\
\hline AGE & $\begin{array}{l}-0.010^{* *} \\
(0.005)\end{array}$ & $\begin{array}{l}-0.010^{*} \\
(0.005)\end{array}$ & $\begin{array}{l}-0.009^{*} \\
(0.005)\end{array}$ & $\begin{array}{l}0.004 \\
(0.007)\end{array}$ & $\begin{array}{l}-0.010^{* *} \\
(0.005)\end{array}$ \\
\hline GROWTH & $\begin{array}{l}0.027^{* * *} \\
(0.009)\end{array}$ & $\begin{array}{l}0.027^{* * *} \\
(0.009)\end{array}$ & $\begin{array}{l}0.027^{* * *} \\
(0.009)\end{array}$ & $\begin{array}{l}0.017 \\
(0.013)\end{array}$ & $\begin{array}{l}0.026^{* * *} \\
(0.008)\end{array}$ \\
\hline MB & $\begin{array}{l}-0.002 \\
(0.002)\end{array}$ & $\begin{array}{l}-0.002 \\
(0.002)\end{array}$ & $\begin{array}{l}-0.002 \\
(0.002)\end{array}$ & $\begin{array}{l}0.001 \\
(0.003)\end{array}$ & $\begin{array}{l}-0.002 \\
(0.002)\end{array}$ \\
\hline LEVG & $\begin{array}{l}0.057^{* *} \\
(0.025)\end{array}$ & $\begin{array}{l}0.057^{* *} \\
(0.024)\end{array}$ & $\begin{array}{l}0.058^{* *} \\
(0.024)\end{array}$ & $\begin{array}{l}0.028 \\
(0.032)\end{array}$ & $\begin{array}{l}0.056^{* *} \\
(0.026)\end{array}$ \\
\hline FSIZE & $\begin{array}{l}0.004 \\
(0.007)\end{array}$ & $\begin{array}{l}0.004 \\
(0.007)\end{array}$ & $\begin{array}{l}0.005 \\
(0.006)\end{array}$ & $\begin{array}{l}0.007 \\
(0.005)\end{array}$ & $\begin{array}{l}0.005 \\
(0.006)\end{array}$ \\
\hline VOL & $\begin{array}{l}0.007 \\
(0.035)\end{array}$ & $\begin{array}{l}0.008 \\
(0.035)\end{array}$ & $\begin{array}{l}0.010 \\
(0.036)\end{array}$ & $\begin{array}{l}0.081 \\
(0.064)\end{array}$ & $\begin{array}{l}0.010 \\
(0.034)\end{array}$ \\
\hline LOSS & $\begin{array}{l}0.008 \\
(0.015)\end{array}$ & $\begin{array}{l}0.008 \\
(0.015)\end{array}$ & $\begin{array}{l}0.008 \\
(0.015)\end{array}$ & $\begin{array}{l}0.012 \\
(0.017)\end{array}$ & $\begin{array}{l}0.007 \\
(0.014)\end{array}$ \\
\hline DIROWN & $\begin{array}{l}0.027^{* *} \\
(0.013)\end{array}$ & $\begin{array}{l}0.059 \\
(0.043)\end{array}$ & $\begin{array}{l}0.131 \\
(0.120)\end{array}$ & & $\begin{array}{l}0.027^{* *} \\
(0.013)\end{array}$ \\
\hline DIR2 & & $\begin{array}{l}-0.042 \\
(0.050)\end{array}$ & $\begin{array}{l}-0.261 \\
(0.329)\end{array}$ & & \\
\hline DIR3 & & & $\begin{array}{l}0.168 \\
(0.234)\end{array}$ & & \\
\hline CRD & & & & & $\begin{array}{l}0.006 \\
(0.008)\end{array}$ \\
\hline INSTOWN & & & & $\begin{array}{l}-0.342^{* * *} \\
(0.112)\end{array}$ & \\
\hline Constant & $\begin{array}{l}-0.111^{* *} \\
(0.052)\end{array}$ & $\begin{array}{l}-0.116^{* *} \\
(0.052)\end{array}$ & $\begin{array}{l}-0.123^{* *} \\
(0.049)\end{array}$ & $\begin{array}{l}-0.013 \\
(0.037)\end{array}$ & $\begin{array}{l}-0.117^{* *} \\
(0.058)\end{array}$ \\
\hline Observations & 908 & 908 & 908 & 907 & 908 \\
\hline $\mathrm{R}^{2}$ & 0.192 & 0.193 & 0.193 & 0.030 & 0.189 \\
\hline $\begin{array}{l}\text { Industry and year } \\
\text { dummies }\end{array}$ & Yes & Yes & Yes & & $\begin{array}{l}\text { Yes (no year } \\
\text { dummy) }\end{array}$ \\
\hline
\end{tabular}

Source: Authors' calculations.

The results show that director ownership maintains its positive sign and statistical significance. However, there is no evidence of a 
nonmonotonic relationship between director ownership and DAC. These findings lead us to conclude that the entrenchment hypothesis holds in Pakistan as opposed to the alignment-of-interest hypothesis.

Similarly, the results reported in column (4) of Table 11 show that institutional ownership is negatively related to DAC - as was the case in Tables 7 to 10. The results for the other explanatory variables are also consistent with those given in Tables 7 to 10. Finally, column (5) reports the results of the regression where average DAC is the dependent variable and director ownership is the main independent variable with other control variables and a crisis-year dummy denoted by CRD. The dummy variable takes the value of 1 for the years 2007 and 2008, and is 0 otherwise.

The purpose of this regression is to find out whether the global financial crisis has had any impact on our findings. CRD has a positive coefficient and is statistically insignificant. Moreover, director ownership and the other variables maintain their signs and statistical significance. These results suggest that the crisis has had no impact on DAC.

\section{Conclusion and Policy Implications}

The aim of this study was to investigate the impact of corporate governance and ownership structure on earnings management for a sample of companies listed on the KSE from 2003 to 2010. Discretionary accruals were used as a proxy for earnings management and estimated using four well-known models: Jones (1991), Dechow et al. (1995), Kasznik (1999), and Kothari et al. (2005). The variable DAC was regressed on several corporate governance and ownership structure variables, along with a sufficiently large set of control variables.

The results indicate that discretionary accruals increase monotonically with the percentage ownership of directors, their spouses, children, and other family members. This supports the view that managers who are more entrenched in a firm can easily influence corporate decisions and manipulate accounting figures in a way that best serves their own interests. This finding is consistent with prior research evidence on the role of dominant directors in expropriating external minority shareholders in Pakistan.

Further, our results indicate that institutional investors play a significant role in preventing managers from engaging in earnings management. We find no evidence that CEO duality, the size of the 
auditing firm, the number of members on the board of directors, and ownership concentration influence discretionary accruals. Among the control variables, firms that are more profitable, are growing, or have higher leverage actively manage their earnings while older firms do not.

Although we have used four different models to ensure our results are not biased, it is possible that accrual models using financial statement data might not accurately divide accruals into discretionary and nondiscretionary components (Siregar \& Utama, 2008). The study's second limitation is that its findings can be generalized for nonfinancial firms only in Pakistan, given that the country's corporate governance environment is different from those elsewhere. Finally, in the absence of organized data on corporate governance and ownership structure, certain variables (such as family ownership and board independence) could not be included.

This research could be extended in several ways. Although we have used institutional ownership as a measure of the stock held by all institutions, future studies could separate intuitional ownership into financial and nonfinancial institutional ownership. Further, financial institutional ownership could be broken down into ownership by banks, insurance companies, mutual funds, and pension funds, etc., to determine how each group of institutions plays a unique role.

Future studies could also use board independence, board meetings, auditor tenure, and family ownership to measure their impact on discretionary accruals. Finally, developing a corporate governance index that takes into account the different clauses of the PCCG would help evaluate the effectiveness of the code in constraining earnings management practices.

In view of our findings, we recommend that the SECP develop a framework that eliminates managers' dominance over the selection of board members and other corporate decisions that might hurt the interests of minority shareholders. The SECP should also ensure free and fair availability of all financial and nonfinancial data in companies' annual reports. Finally, it should ensure that all firms' annual reports include comprehensive profiles of their board members and CEO so that shareholders can distinguish between executive and nonexecutive board members and highlight their academic and professional experience. 


\section{References}

Aaker, H., \& Gjesdal, F. (2010). Do models of discretionary accruals detect actual earnings management via inventory? A comparison of general and specific models (Working paper). Bodø: University of Nordland.

Abdelghany, K. E. (2005). Measuring the quality of earnings. Managerial Auditing Journal, 20(9), 1001-1015.

Abdoli, M. R. (2011). Relation of nonexecutive directors and ownership concentration with discretionary accrual accounting. Australian Journal of Business and Management Research, 1(4), 93-101.

Abdul Rahman, R., \& Haniffa, R. (2005). The effect of role duality on corporate performance in Malaysia. Corporate Ownership and Control, 2(2), 40-47.

Abdullah, F., Shah, A., Iqbal, A. M., \& Gohar, R. (2011). Investors' power and the dividend cost minimization model: Which one better explains the dividend policy in Pakistan? African Journal of Business Management, 5(24), 10747-10759.

Abdullah, F., Shah, A., \& Khan, S. U. (2012). Firm performance and the nature of agency problems in insiders-controlled firms: Evidence from Pakistan. Pakistan Development Review, 51(4), 161-183.

Al-Fayoumi, N., Abuzayed, B., \& Alexander, D. (2010). Ownership structure and earnings management in emerging markets: The case of Jordan. International Research Journal of Finance and Economics, 38, $28-47$.

Ali, S. M., Salleh, N. M., \& Hassan, M. S. (2008). Ownership structure and earnings management in Malaysian listed companies: The size effect. Asian Journal of Business and Accounting, 1(2), 89-116.

Alves, S. (2012). Ownership structure and earnings management: Evidence from Portugal. Australasian Accounting, Business and Finance Journal, 6(1), 57-74.

Anderson, R. C., Mansi, S. A., \& Reeb, D. M. (2003). Founding family ownership and the agency cost of debt. Journal of Financial Economics, 68(2), 263-285.

Ashari, N., Koh, H. C., Tan, S. L., \& Wong, W. H. (1994). Factors affecting income smoothing among listed companies in Singapore. Accounting Business Research, 24(96), 291-301. 
Ashbaugh-Skaife, H., Collins, D. W., Kinney, W. R., \& LaFond, R. (2008). The effect of SOX internal control deficiencies and their remediation on accrual quality. The Accounting Review, 83(1), 217-250.

Bacon, J. (1973). Corporate directorship practices: Membership and committees of the board. New York, NY: Conference Board.

Badolato, P. G., Donelson, D. C., \& Ege, M. (2014). Audit committee financial expertise and earnings management: The role of status. Journal of Accounting and Economics, 58(2), 208-230.

Banderlipe, M. S. (2009). The impact of selected corporate governance variables in mitigating earnings management in the Philippines. DLSU Business and Economics Review, 19(1), 17-27.

Bartov, E., Gul, F. A., \& Tsui, J. S. L. (2000). Discretionary accruals models and audit qualifications. Journal of Accounting and Economics, 30, $421-452$.

Beasley, M. S. (1996). An empirical analysis of the relation between the board of director composition and financial statement fraud. The Accounting Review, 71(4), 443-465.

Beatty, A., Chamberlain, S., \& Magliolo, J. (1995). Managing financial reports of commercial banks: The influence of taxes, regulatory capital and earnings. Journal of Accounting Research, 33(2), 231-262.

Bebchuk, L. (1994). Efficient and inefficient sales of corporate control. Quarterly Journal of Economics, 109(4), 957-994.

Becker, C., DeFond, M., Jiambalvo, J., \& Subramanyam, K. R. (1998). The effects of audit quality on earnings management. Contemporary Accounting Research, 15(1), 1-24.

Bédard, J., Chtourou, S. M., \& Courteau, L. (2004). The effect of audit committee expertise, independence and activity on aggressive earnings management. Auditing: A Journal of Practice and Theory, 23(2), 55-79.

Bekiris, F. V., \& Doukakis, L. C. (2011). Corporate governance and accruals earnings management. Managerial and Decision Economics, 32(7), 439-456.

Beneish, M. D. (2001). Earnings management: A perspective. Managerial Finance, 27(12), 3-17. 
Berle, A., \& Means, G. C. (1932). The modern corporation and private property. New York, NY: Macmillan.

Bhide, A. (1993). The hidden costs of stock market liquidity. Journal of Financial Economics, 34(1), 31-51.

Bushee, B. J. (1998). The influence of institutional investors on myopic R\&D investment behavior. The Accounting Review, 73, 305-333.

Bushee, B. J. (2001). Do institutional investors prefer near-term earnings over long-run value? Contemporary Accounting Research, 18(2), 207-246.

Butler, M., Leone, A. J., \& Willenborg, M. (2004). An empirical analysis of auditor reporting and its association with abnormal accruals. Journal of Accounting and Economics, 37(2), 139-165.

Chaganti, R. S., Mahajan, V., \& Sharma, S. (1985). Corporate board size, composition and corporate failures in retailing industry. Journal of Management Studies, 22(4), 400-417.

Chambers, R. J. (1999). The poverty of accounting disclosure. Abacus, 35(3), 241-251.

Charitou, A., Lambertides, N., \& Trigeorgis, L. (2007). Earnings behavior of financially distressed firms: The role of institutional ownership. Abacus, 43(3), 271-296.

Chen, G., Firth, M., Gao, D. N., \& Rui, O. M. (2006). Ownership structure, corporate governance, and fraud: Evidence from China. Journal of Corporate Finance, 12(3), 424-448.

Chen, K. Y., Elder, R. J., \& Hsieh, Y.-M. (2007). Corporate governance and earnings management: The implications of corporate governance best-practice principles for Taiwanese listed companies. Journal of Contemporary Accounting and Economics, 3(2), 73-105.

Chen, K. Y., Lin, K. L., \& Zhou, J. (2007). Audit quality and earnings management for Taiwan IPO firms. Managerial Auditing Journal, 20(1), 86-104.

Chen, X., Cheng, Q., \& Wang, X. (2010). Does increased board independence reduce earnings management? Evidence from recent regulatory reforms (Mimeo). University of Wisconsin-Madison and Chinese University of Hong Kong. 
Cheng, C. A., \& Reitenga, A. (2000, July). Institutional investors and discretionary accruals. Paper presented at the 2nd AAA/BAA Globalization Conference, Cambridge, UK.

Chia, Y. M., Lapsley, I., \& Lee, H. W. (2007). Choice of auditors and earnings management during the Asian financial crisis. Managerial Auditing Journal, 22(2), 177-196.

Chin, K. M., Firth, M., \& Rui, O. M. (2006). Earnings management, corporate governance, and the market performance of seasoned equity offerings in Hong Kong. Journal of Contemporary Accounting and Economics, 2(1), 73-98.

Choi, J.-H., Jeon, K.-A., \& Park, J.-I. (2004). The role of audit committees in decreasing earnings management: Korean evidence. International Journal of Accounting, Auditing and Performance Evaluation, 1(1), 37-60.

Chung, R., Firth, M., \& Kim, J.-B. (2002). Institutional monitoring and opportunistic earnings management. Journal of Corporate Finance, 8(1), 29-48.

Chung, H., \& Kallapur, S. (2003). Client importance, non-audit services, and abnormal accruals. The Accounting Review, 78(4), 931-955.

Claessens, S., Djankov, S., \& Lang, L. H. P. (2000). The separation of ownership and control in East Asian corporations. Journal of Financial Economics, 58, 81-112.

Coffee, J. (1991). Liquidity versus control: The institutional investor as corporate monitor. Columbia Law Review, 91, 1277-1366.

Cornett, M., Marcus, A., \& Tehranian, H. (2008). Earnings management, corporate governance, and financial performance. Journal of Financial Economics, 87, 357-373.

Daily, C. M., \& Dalton, D. R. (1997). CEO and board chair roles held jointly or separately: Much ado about nothing? Academy of Management Executive, 11(3), 11-20.

Dalton, D. R., Daily, C. M., Ellstrand, A., \& Johnson, J. (1998). Metaanalytic reviews of board composition, leadership structure, and financial performance. Strategic Management Journal, 19, 269-290. 
Dalton, D. R., Daily, C. M., Johnson, J. L., \& Ellstrand, A. E. (1999). Number of directors and financial performance: A meta-analysis. Academy of Management Journal, 42(6), 674-686.

DeAngelo, L. E. (1981). Auditor size and audit quality. Journal of Accounting and Economics, 3(3), 183-199.

Dechow, P. M. (1994). Accounting earnings and cash flows as measures of firm performance: The role of accounting accruals. Journal of Accounting and Economics, 18, 3-42.

Dechow, P. M., \& Skinner, D. (2000). Earnings management: Reconciling the views of accounting academics, practitioners, and regulators. Accounting Horizons, 14(2), 235-250.

Dechow, P. M., Sloan, R. G., \& Sweeney, A. P. (1995). Detecting earnings management. The Accounting Review, 70, 193-225.

Dechow, P. M., Sloan, R. G., \& Sweeney, A. P. (1996). Causes and consequences of earnings manipulation: An analysis of firms subject to enforcement actions by the SEC. Contemporary Accounting Research, 13, 1-36.

DeFond, M. L., \& Jiambalvo, J. (1994). Debt covenant violation and manipulation of accruals: Accounting choice in troubled companies. Journal of Accounting and Economics, 17(1/2), 145-176.

Demsetz, H., \& Lehn, K. (1985). The structure of corporate ownership: Causes and consequences. Journal of Political Economy, 93, 1155-1177.

Dhaliwal, D., Naiker, V., \& Navissi, F. (2010). The association between accruals quality and the characteristics of accounting experts and mix of expertise on audit committees. Contemporary Accounting Research, 27, 787-827.

Eccles, R. G. (2001). The value reporting revolution: Moving beyond the earnings game. New York, NY: John Wiley.

Fama, E. (1980). Agency problems and the theory of the firm. Journal of Political Economy, 88(2), 88-107.

Fan, P. H., \& Wong T. J. (2002). Corporate ownership structure and the informativeness of accounting earnings in East Asia. Journal of Accounting and Economics, 33, 401-425. 
Finkelstein, S., \& D'Aveni, R. A. (1994). CEO duality as a double-edged sword: How boards of directors balance entrenchment avoidance and unity of command. Academy of Management Journal, 37(5), 1079-1108.

Francis, J., Maydew, E., \& Sparks, H. (1999). The role of Big 6 auditors in the credible reporting of accruals. Auditing: A Journal of Practice and Theory, 18, 17-34.

García-Meca, E., \& Ballesta, J. P. S. (2009). Corporate governance and earnings management: A meta-analysis. Corporate Governance: An International Review, 17(5), 594-610.

Haniffa, R., \& Cooke, T. (2002). Culture, corporate governance and disclosure in Malaysian corporations. Abacus, 38, 317-349.

Hashim, H. A., \& Devi, S. S. (2008). Board independence, CEO duality and accrual management: Malaysian evidence. Asian Journal of Business and Accounting, 1(1), 27-46.

Healy, P. M., \& Wahlen, J. (1999). A review of the earnings management literature and its implications for standard setting. Accounting Horizons, 13(4), 365-384.

Herman, E. S. (1981). Corporate control, corporate power. Cambridge: Cambridge University Press.

Hsu, G. C. M., \& Koh, P. S. (2005). Does the presence of institutional investors influence accruals management? Evidence from Australia. Corporate Governance: An International Review, 13(6), 809-823.

Javid, A. Y., \& Iqbal, R. (2008). Ownership concentration, corporate governance and firm performance: Evidence from Pakistan. Pakistan Development Review, 47(4), 643-659.

Jensen, M. C. (1993). The modern industrial revolution, exit, and the failure of internal control systems. Journal of Finance, 48(3), 831-880.

Jensen, M. C., \& Meckling, W. (1976). Theory of the firm: Managerial behavior, agency costs and ownership structure. Journal of Financial Economics, 3(4), 305-360. 
Johnson, V. E., Khurana, I. K., \& Reynolds, J. K. (2002). Audit firm tenure and the quality of financial reports. Contemporary Accounting Research, 19(4), 637-660.

Jones, J. J. (1991). The effects of foreign trade regulation on accounting choices. Journal of Accounting Research, 29(2), 193-228.

Jones, K., Krishnan, G., \& Melendrez, K. (2007). Do models of discretionary accruals detect actual cases of fraudulent and restated earnings? An empirical evaluation (Mimeo). George Mason University and Louisiana State University.

Kao, L., \& Chen, A. (2004). The effects of board characteristics on earnings management. Corporate Ownership and Control, 1(3), 96-107.

Karamanou, I., \& Vafeas, N. (2005). The association between corporate boards, audit committees, and management earnings forecasts: An empirical analysis. Journal of Accounting Research, 43, 453-486.

Kasznik, R. (1999). On the association between voluntary disclosure and earnings management. Journal of Accounting Research, 37(1), 57-81.

Kim, Y., Liu, C., \& Rhee, S. G. (2003). The relation of earnings management to firm size (Working paper). University of Hawaii.

Kim, H. J., \& Yoon, S. S. (2008). The impact of corporate governance on earnings management in Korea. Malaysian Accounting Review, 7(1), $43-59$.

Klein, A. (2002). Audit committee, board of director characteristics and earnings management. Journal of Accounting and Economics, 33, 375-400.

Koh, P. S. (2003). On the association between institutional ownership and aggressive corporate earnings management in Australia. British Accounting Review, 35, 105-128.

Kosnik, R. D. (1987). Greenmail: A study of board performance in corporate governance. Administrative Science Quarterly, 32, 163-185.

Kothari, S. P., Leone, A. J., \& Wasley, C. E. (2005). Performance-matched discretionary accruals. Journal of Accounting and Economics, 39, 163-197. 
La Porta, R., López-de-Silanes, F., Shleifer, A., \& Vishny, R. (1999). Corporate ownership around the world. Journal of Finance, 54, 471-517.

La Porta, R., López-de-Silanes, F., Shleifer, A., \& Vishny, R. (2000). Investor protection and corporate governance. Journal of Financial Economics, 58, 3-27.

Lipton, M., \& Lorsch, J. W. (1992). A modest proposal for improved corporate governance. Business Lawyer, 48(1), 59-77.

Liu, Q., \& Lu, Z. (2007). Corporate governance and earnings management in the Chinese listed companies: A tunneling perspective. Journal of Corporate Finance, 13, 881-906.

Lo, A. W. Y., Wong, R. M. K., \& Firth, M. (2010). Can corporate governance deter management from manipulating earnings? Evidence from related-party sales transactions in China. Journal of Corporate Finance, 16(2), 225-235.

Majumdar, S. K., \& Nagarajan, A. (1997). The impact of changing stock ownership patterns in the United States: Theoretical implications and some evidence. Revue d'Économie Industrielle, 82(4), 39-54.

Mitra, S. (2002). The impact of institutional stock ownership on a firm's earnings management practice: An empirical investigation. Unpublished doctoral dissertation, Louisiana State University, LA.

Monks, R., \& Minow, N. (1995). Corporate governance. Cambridge, MA: Blackwell Business.

Morck, R., Shleifer, A., \& Vishny, R. W. (1988). Management ownership and market valuation: An empirical analysis. Journal of Financial Economics, 20, 293-315.

Moses, O. D. (1987). Income smoothing and incentives: Empirical tests using accounting changes. The Accounting Review, 62(2), 259-377.

Palmrose, Z.-V. (1988). An analysis of auditor litigation and audit service quality. The Accounting Review, 63, 55-73.

Pearce, J. A., \& Zahra, S. A. (1992). Board composition from a strategic contingency perspective. Journal of Management Studies, 29(4), 411438. 
Peasnell, K. V., Pope, P. F., \& Young, S. (2000a). Board monitoring and earnings management: Do outside directors influence abnormal accruals? (Mimeo). Lancaster University, UK.

Peasnell, K. V., Pope, P. F., \& Young, S. (2000b). Accrual management to meet earnings targets: UK evidence pre- and post-Cadbury. British Accounting Review, 32(4), 415-445.

Peng, M. W., Zhang, S., \& Li, X. (2007). CEO duality and firm performance during China institutional transitions. Management and Organization Review, 3(2), 205-225.

Persons, O. S. (2006). Corporate governance and nonfinancial reporting fraud. Journal of Business and Economic Studies, 12(1), 27-40.

Prawitt, D. F., Smith, J. L., \& Wood, D. A. (2009). Internal audit quality and earnings management. The Accounting Review, 84, 1255-1280.

Rahman, A. R., \& Ali, F. (2006). Board, audit committee, culture and earnings management: Malaysian evidence. Managerial Auditing Journal, 21(7), 783-804.

Rajgopal, S., \& Venkatachalam, M. (1997). The role of institutional investors in corporate governance: An empirical investigation (Working Paper No. 1436). Stanford, CA: Stanford Graduate School of Business.

Ramsay, I., \& Blair, M. (1993). Ownership concentration, institutional investment and corporate governance: An empirical investigation of 100 Australian companies. Melbourne University Law Review, 19, 153-194.

Rao, N., \& Dandale, S. (2008). Earnings management: A study of equity rights issues in India. ICFAI Journal of Applied Finance, 14, 20-34.

Roodposhti, F. R., \& Chashmi, S. A. N. (2011). The impact of corporate governance mechanisms on earnings management. African Journal of Business Management, 5(11), 4143-4151.

Rozeff, M. S. (1982). Growth, beta and agency costs as determinants of dividend payout ratios. Journal of Financial Research, 5, 249-259.

Saleh, M. N., Iskandar T. M., \& Rahmat, M. M. (2005). Earnings management and board characteristics: Evidence from Malaysia. Jurnul Pengurusan, 24, 77-103. 
Schipper, K. (1989). Commentary on earnings management. Accounting Horizons, 3, 91-102.

Shah, S. Z. A., Butt, S. A., \& Hassan, A. (2009). Corporate governance and earnings management: An empirical evidence from Pakistani listed companies. European Journal of Scientific Research, 26(4), 624-638.

Shah, S. Z. A., Zafar, N., \& Durrani, T. K. (2009). Board composition and earnings management: An empirical evidence from Pakistani listed companies. Middle Eastern Finance and Economics, 3, 28-38.

Shen, C.-H., \& Chih, H.-L. (2007). Earnings management and corporate governance in Asia's emerging markets. Corporate Governance: An International Review, 15(5), 999-1021.

Shleifer, A., \& Vishny, R. (1997). A survey of corporate governance. Journal of Finance, 52, 737-783.

Siregar, S. V., \& Utama, S. (2008). Type of earnings management and the effect of ownership structure, firm size, and corporate governance practices: Evidence from Indonesia. International Journal of Accounting, 43, 1-27.

Stiglitz, J. E. (1985). Credit markets and the control of capital. Journal of Money, Credit and Banking, 17, 133-152.

Subramanyam, K. (1996). The pricing of discretionary accruals. Journal of Accounting and Economics, 18, 249-281.

Sun, L., \& Rath, S. (2009). An empirical analysis of earnings management in Australia. International Journal of Human and Social Sciences, 4(14), 1069-1085.

Sveilby, K. E. (2001). A knowledge-based theory of the firm to guide strategy formulation. Journal of Intellectual Capital, 2(4), 344-358.

Sweeney, A. P. (1994). Debt-covenant violations and managers' accounting responses. Journal of Accounting and Economics, 17(3), 281-308.

Teshima, N., \& Shuto, A. (2008). Managerial ownership and earnings management: Theory and empirical evidence from Japan. Journal of International Financial Management and Accounting, 19(2), 107-132. 
Tie, R. (1999). Concerns over auditing quality complicate the future of accounting. Journal of Accountancy, 188(6), 14-15.

Wallace, W. (1980). The economic role of the audit in free and regulated markets. New York, NY: University of Rochester.

Wang, D. (2006). Founding family ownership and earnings quality. Journal of Accounting Research, 44(3), 619-656.

Warfield, T., Wild, J. J., \& Wild, K. L. (1995). Managerial ownership, accounting choices, and informativeness of earnings. Journal of Accounting and Economics, 20, 61-91.

Worrell, D. L., Nemec, C., \& Davidson, W. N. (1997). One hat too many: Key executive plurality and shareholder wealth. Strategic Management Journal, 18(6), 499-507.

Xie, B., Davidson, W., \& DaDalt, P. (2003). Earnings management and corporate governance: The roles of the board and the audit committee. Journal of Corporate Finance, 9(3), 295-317.

Yang, W. S., Chun, L. S., \& Shamsher, M. R. (2009). The effect of board structure and institutional ownership structure on earnings management. International Journal of Economics and Management, 3(2), 332-353.

Yermack, D. (1996). Higher valuation of companies with a small board of directors. Journal of Financial Economics, 40(2), 185-211.

Yu, F. (2008). Corporate governance and earnings management. Journal of Financial Economics, 88, 245-271.

Zahra, S. A., \& Pearce, J. A. (1989). Board of directors and corporate financial performance: A review and integrative model. Journal of Management, 15, 291-334.

Zhou, J., \& Chen, K. Y. (2004). Audit committee, board characteristics and earnings management by commercial banks (Mimeo). SUNY at Binghamton, NY, and National Cheng Kung University, Taiwan.

Zulkafli, A. H., Abdul-Samad, M. F., \& Ismail, M. I. (2005). Corporate governance in Malaysia. Kuala Lumpur: Malaysian Institute of Corporate Governance. 